\title{
Trimethoxylated Halogenated Chalcones as Dual Inhibitors of MAO-B and BACE-1 for the Treatment of Neurodegenerative Disorders
}

\author{
Vishal Payyalot Koyiparambath ${ }^{1}\left(\mathbb{D}\right.$, Jong Min Oh ${ }^{2}$, Ahmed Khames ${ }^{3} \mathbb{D}$, Mohamed A. Abdelgawad ${ }^{4,5} \mathbb{D}$, \\ Aathira Sujathan Nair ${ }^{1}$, Lekshmi R. Nath ${ }^{6}$, Nicola Gambacorta ${ }^{7}$, Fulvio Ciriaco ${ }^{8}$, Orazio Nicolotti ${ }^{7}$ (D), \\ Hoon Kim ${ }^{2, *}$ (D) and Bijo Mathew ${ }^{1, *}$
}

check for updates

Citation: Koyiparambath, V.P.; Oh, J.M.; Khames, A.; Abdelgawad, M.A.; Nair, A.S.; Nath, L.R.; Gambacorta, N.; Ciriaco, F.; Nicolotti, O.; Kim, H.; et al. Trimethoxylated Halogenated Chalcones as Dual Inhibitors of MAO-B and BACE-1 for the Treatment of Neurodegenerative Disorders. Pharmaceutics 2021, 13, 850. https://doi.org/10.3390/ pharmaceutics 13060850

Academic Editors: David Ramírez and Ana Martínez

Received: 14 May 2021

Accepted: 5 June 2021

Published: 8 June 2021

Publisher's Note: MDPI stays neutral with regard to jurisdictional claims in published maps and institutional affiliations.

Copyright: (c) 2021 by the authors. Licensee MDPI, Basel, Switzerland. This article is an open access article distributed under the terms and conditions of the Creative Commons Attribution (CC BY) license (https:// creativecommons.org/licenses/by/ $4.0 /)$.
1 Department of Pharmaceutical Chemistry, AIMS Health Sciences Campus, Amrita School of Pharmacy, Amrita Vishwa Vidyapeetham, Kochi 682041, India; vishalpk11@gmail.com (V.P.K.); sujuaathira@gmail.com (A.S.N.)

2 Department of Pharmacy, Research Institute of Life Pharmaceutical Sciences, Sunchon National University, Suncheon 57922, Korea; ddazzo005@naver.com

3 Department of Pharmaceutics and Industrial Pharmacy, College of Pharmacy, Taif University, P.O. Box-11099, Taif 21944, Saudi Arabia; dr_akhames@yahoo.com

4 Department of Pharmaceutical Chemistry, College of Pharmacy, Jouf University, Sakaka 72341, Saudi Arabia; mhmdgwd@ju.edu.sa

5 Department of Pharmaceutical Organic Chemistry, Faculty of Pharmacy, Beni-Suef University, Beni Suef 62514, Egypt

6 Department of Pharmacogonosy, Amrita School of Pharmacy, Amrita Vishwa Vidyapeetham, AIMS Health Sciences Campus, Kochi 682041, India; lrnvaishnav@gmail.com

7 Dipartimento di Farmacia—Scienze del Farmaco, Università degli Studi di Bari “Aldo Moro", Via E. Orabona, 4, I-70125 Bari, Italy; nicola.gambacorta1@uniba.it (N.G.); orazio.nicolotti@uniba.it (O.N.)

8 Dipartimento di Chimica, Università degli Studi di Bari “Aldo Moro", Via E. Orabona, 4, I-70125 Bari, Italy; fulvio.ciriaco@uniba.it

* Correspondence: hoon@sunchon.ac.kr (H.K.); bijovilaventgu@gmail.com (B.M.)

Abstract: Six halogenated trimethoxy chalcone derivatives ( $\mathrm{CH} 1-\mathrm{CH} 6)$ were synthesized and spectrally characterized. The compounds were further evaluated for their inhibitory potential against monoamine oxidases (MAOs) and $\beta$-secretase (BACE-1). Six compounds inhibited MAO-B more effectively than MAO-A, and the $2^{\prime}, 3^{\prime}, 4^{\prime}$-methoxy moiety in $\mathrm{CH} 4-\mathrm{CH} 6$ was more effective for MAO-B inhibition than the $2^{\prime}, 4^{\prime}, 6^{\prime}$-methoxy moiety in $\mathrm{CH} 1-\mathrm{CH} 3$. Compound $\mathrm{CH} 5$ most potently inhibited MAO-B, with an $\mathrm{IC}_{50}$ value of $0.46 \mu \mathrm{M}$, followed by $\mathrm{CH} 4\left(\mathrm{IC}_{50}=0.84 \mu \mathrm{M}\right)$. In $2^{\prime}, 3^{\prime}, 4^{\prime}$-methoxy derivatives $(\mathrm{CH} 4-\mathrm{CH}$ ), the order of inhibition was $-\mathrm{Br}$ in $\mathrm{CH} 5>-\mathrm{Cl}$ in $\mathrm{CH} 4>-\mathrm{F}$ in $\mathrm{CH} 6$ at the para-position in ring $\mathrm{B}$ of chalcone. $\mathrm{CH} 4$ and $\mathrm{CH} 5$ were selective for MAO-B, with selectivity index (SI) values of 15.1 and 31.3, respectively, over MAO-A. CH4 and CH5 moderately inhibited BACE-1 with $\mathrm{IC}_{50}$ values of 13.6 and $19.8 \mu \mathrm{M}$, respectively. When $\mathrm{CH} 4$ and $\mathrm{CH} 5$ were assessed for their cell viability studies on the normal African Green Monkey kidney cell line (VERO) using MTT assays, it was noted that both compounds were found to be safe, and only a slightly toxic effect was observed in concentrations above $200 \mu \mathrm{g} / \mathrm{mL}$. CH4 and CH5 decreased reactive oxygen species (ROS) levels of VERO cells treated with $\mathrm{H}_{2} \mathrm{O}_{2}$, indicating both compounds retained protective effects on the cells by antioxidant activities. All compounds showed high blood brain barrier permeabilities analyzed by a parallel artificial membrane permeability assay (PAMPA). Molecular docking and ADME prediction of the lead compounds provided more insights into the rationale behind the binding and the CNS drug likeness. From non-test mutagenicity and cardiotoxicity studies, $\mathrm{CH} 4$ and $\mathrm{CH} 5$ were nonmutagenic and non-/weak-cardiotoxic. These results suggest that $\mathrm{CH} 4$ and $\mathrm{CH} 5$ could be considered candidates for the cure of neurological dysfunctions.

Keywords: monoamine oxidase; $\beta$-secretase; chalcones; reversibility; cytotoxicity; molecular docking 


\section{Introduction}

A well-known aspect of monoamine oxidases (MAOs) is their role in metabolizing various types of biogenic amines, which can impart a crucial role in modulating the central nervous system (CNS) neurotransmitter functions [1]. The malfunctioning of these neurotransmitters by the oxidative deamination process by MAOs leads to a variety of neurodegenerative disorders (NDDs) such as Alzheimer's disease (AD) and Parkinson's disease (PD) [2-4]. Among the MAO family, selective inhibitors of MAO-A can be employed for managing various depressive states, and at the same time, inhibitors of MAO-B can be widely used for the adjuvant therapy for NDDs $[5,6]$

Subsequently, MAOs have been extensively researched, with over 23,000 publications dealing with their properties, enzymology, functions, and specific inhibitors from various classes, according to the PubMed database [7]. Monoamine oxidase was chosen as a target here since it is a common enzyme for various neurological disorders and has the benefit in kinetics studies of allowing us to determine how quickly enzymes will function in tissues with the substrate concentrations they are likely to encounter, as well as how different substrates will fight for the enzyme [8]. The life of two isoforms, MAO-A and MAO-B, each with distinct structural features, has inspired clinical strategies to develop isoform-tailored inhibitors that might be used to treat a wide range of depressive diseases and CNS-related disorders $[9,10]$.

$\beta$-secretase (BACE-1) is a crucial cleaving enzyme that takes part in the degradation of the amyloid precursor protein (APP) [11]. This cleavage process leads to the formation of amyloid $\beta(\mathrm{A} \beta)$ protein, which is neurotoxic and can trigger the neurodegeneration and plaque deposition in the AD brain [12]. Numerous studies have documented that inhibitors of BACE- 1 have a prominent role in diminishing the $A \beta$ concentration in the brain and thwarting the progression of $\mathrm{AD}$ [13]. Considering the benefits of a multitarget directed ligand (MTDL) approach by inhibiting MAO-B and A $\beta$ production would be of great interest in $A D$ therapy. Very limited literature has been reported regarding the development of dual-acting MAO-B and BACE-1 inhibitors [14,15].

Chalcones are well-known structural motifs with $\alpha, \beta$-unsaturated ketones and are open-chain flavonoids [16]. The presence of three rotatable bonds and the Michael acceptor nature of the linker present in the chalcone scaffold provided a remarkable ability to reach different enzyme targets [17]. Thus, many pharmacological active profiles involve chalconecontaining compounds, including anti-tumor, anti-diabetic, anti-inflammatory, and anti-AD agents [18-22]. Based upon the wealth of information, halogens have now established themselves as a central player in supramolecular chemistry with wide applications in medicinal chemistry [23]. The electron-accepting nature of halogens can preferably promote more non-covalent hydrophobic interactions in several enzyme targets [24]. A recent report documented that the presence of halogens in various classes of MAO inhibitors resulted in improved MAO-B selectivity by the stabilizing property of halogen bonding in the inhibitor-binding cavity (IBC) of the enzyme [25].

Based on the previous studies, in the simple framework of non-nitrogenous based chalcones, the selective and potent candidates against the MAO-B isoform were characterized by the presence of methoxyl or methyl substituents at the para or ortho positions of phenyl ring A [26-31]. At the same time, the presence of halogens and electron-releasing substituents, preferably methoxy, dimethylamino, ethyl acetohydroxamate, and ethoxy on the para position of phenyl ring $\mathbf{B}$, are well tolerated in the MAO-B inhibition [32-50]. Based upon the existing literature, it is clearly proved that $99 \%$ of chalcone derived compounds are a selective and reversible type of MAO-B inhibitors [51-53]. In this scenario, our attention is mainly focused on the development of two series by the incorporation of three methoxy pharmacophores on the A ring of the phenyl ring of chalcones at the positions of $2^{\prime}, 4^{\prime}$, and $6^{\prime}$ and $2^{\prime}, 3^{\prime}$, and $4^{\prime}$, respectively. A variety of halogens such as chlorine, bromine, and fluorine have been also introduced on the para position on the $\mathbf{B}$ ring phenyl unit. To the best of our knowledge, such a design strategy has not been reported regarding the 
effect and orientation of various halogens and trimethoxyl groups on chalcones framework for the development of multi-targeted MAO-B/BACE-1 inhibitors.

The present study emphasizes the synthesis of $2^{\prime}, 4^{\prime}$, and $6^{\prime}$ and $2^{\prime}, 3^{\prime}$, and $4^{\prime}$ trimethoxylated halogenated chalcones and the evaluation of their MAO-A, MAO-B, and BACE-1 inhibition. The lead molecules were further studied in kinetics, reversibility, cytotoxicity, and reactive oxygen species (ROS) assays. A molecular docking study established the detailed protein-ligand binding interactions of the lead molecules in their respective active sites of enzyme targets.

\section{Materials and Methods}

2.1. Synthesis

A mixture of trimethoxy acetophenone ( $0.01 \mathrm{~mol})$, para-substituted halogenated benzaldehyde $(0.01 \mathrm{~mol})$, and $50 \% \mathrm{KOH}$ was added to $15 \mathrm{~mL}$ of methanol and was kept stirring at room temperature for $15 \mathrm{~h}$ [54]. The resulting solution was then filtered, washed with water, and dried. The product was then recrystallized from methanol-yielded pure crystals. The synthetic route for the titled derivatives is depicted in Scheme 1.<smiles>[Y]c1ccc(/C=C/C(=O)c2c([R9])cc(Br)c(C=NC(=O)c3cc([Y])ccc3C(=O)O)c2[R1])cc1</smiles>

\footnotetext{
$\begin{array}{lllll}\mathrm{R}_{1} & \mathrm{R}_{2} & \mathrm{R}_{3} & \mathrm{R}_{4} & \mathrm{X}\end{array}$

CH1: $\mathrm{OCH}_{3} \quad \mathrm{H} \quad \mathrm{OCH}_{3} \mathrm{OCH}_{3} \quad \mathrm{Cl}$

CH2: $\mathrm{OCH}_{3} \quad \mathrm{H} \quad \mathrm{OCH}_{3} \mathrm{OCH}_{3} \quad \mathrm{Br}$

CH3: $\mathrm{OCH}_{3} \quad \mathrm{H} \quad \mathrm{OCH}_{3} \mathrm{OCH}_{3} \quad \mathrm{~F}$
}

Scheme 1. Synthetic route for $(\mathrm{CH} 1-\mathrm{CH} 6)$ series.

2.1.1. (E)-3-(4-chlorophenyl)-1-(2,4,6-trimethoxyphenyl)prop-2-en-1-one (CH1)

M.P: $136-138{ }^{\circ} \mathrm{C} ;{ }^{1} \mathrm{H}$ NMR $\left(500 \mathrm{MHz}, \mathrm{CDCl}_{3}\right) \delta: 3.77\left(\mathrm{~s}, 6 \mathrm{H}, \mathrm{Ar}-2^{\prime} \mathrm{OCH}_{3}, \mathrm{Ar}-6^{\prime} \mathrm{OCH}_{3}\right)$, $3.86\left(\mathrm{~s}, 3 \mathrm{H}, \mathrm{Ar}-4^{\prime} \mathrm{OCH}_{3}\right), 6.15$ (s, 2H, Ar- $\left.3^{\prime} \mathrm{C} \underline{\mathrm{H}}, \mathrm{Ar}-5^{\prime} \mathrm{C} \underline{\mathrm{H}}\right), 6.94-6.91(1 \mathrm{H}, \mathrm{d}, J=15.0 \mathrm{~Hz}$, $\left.-\mathrm{CH}_{\alpha}\right), 7.33-7.30\left(1 \mathrm{H}, \mathrm{d}, J=15.0 \mathrm{~Hz},-\mathrm{CH}_{\beta}\right), 7.34(2 \mathrm{H}, \mathrm{d}, \mathrm{Ar}-3 \mathrm{C} \underline{\mathrm{H}}, \mathrm{Ar}-5 \mathrm{C} \underline{\mathrm{H}}), 7.46(2 \mathrm{H}$, $\mathrm{d}, \mathrm{Ar}-2 \underline{\mathrm{H}}, \mathrm{Ar}-6 \underline{\mathrm{H}}) .{ }^{13} \mathrm{C}-\mathrm{NMR}\left(500 \mathrm{MHz}, \mathrm{CDCl}_{3}\right) \delta:$ 193.91, 162.57, 158.93, 142.39, 136.01, $133.55,129.54,129.39,129.09,111.60,90.69$, 55.94. Molecular formula $\mathrm{C}_{18} \mathrm{H}_{17} \mathrm{ClO}_{4}$ (HRMS) Calculated $=332.7781$, Observed $=333.0892$.

2.1.2. (E)-3-(4-bromophenyl)-1-(2,4,6-trimethoxyphenyl)prop-2-en-1-one ( $\mathrm{CH} 2)$

M.P: $120-122{ }^{\circ} \mathrm{C}^{1}{ }^{1} \mathrm{H}$ NMR $\left(500 \mathrm{MHz}, \mathrm{CDCl}_{3}\right) \delta: 3.77\left(\mathrm{~s}, 6 \mathrm{H}, \mathrm{Ar}-2^{\prime} \mathrm{OCH}_{3}, \mathrm{Ar}-6^{\prime} \mathrm{OCH}_{3}\right)$, 3.85 (s, 3H, Ar-4' $\left.\mathrm{OCH}_{3}\right), 6.15\left(\mathrm{~s}, 2 \mathrm{H}, \mathrm{Ar}-3^{\prime} \mathrm{C} \underline{\mathrm{H}}, \mathrm{Ar}-5^{\prime} \mathrm{C} \underline{\mathrm{H}}\right), 6.96-6.93(1 \mathrm{H}, \mathrm{d}, J=15.0 \mathrm{~Hz}$, $\left.-\mathrm{CH}_{\alpha}\right), 7.29-7.26\left(1 \mathrm{H}, \mathrm{d}, J=15.0 \mathrm{~Hz},-\mathrm{CH}_{\beta}\right), 7.39-7.37(2 \mathrm{H}, \mathrm{d}, \mathrm{Ar}-3 \mathrm{C} \underline{\mathrm{H}}, \mathrm{Ar}-5 \mathrm{C} \underline{\mathrm{H}}), 7.50-7.48$ $(2 \mathrm{H}, \mathrm{d}, \mathrm{Ar}-2 \underline{\mathrm{H}}, \mathrm{Ar}-6 \underline{\mathrm{H}}) .{ }^{13} \mathrm{C}-\mathrm{NMR}\left(500 \mathrm{MHz}, \mathrm{CDCl}_{3}\right) \delta: 193.84,162.59,158.95,142.38,134.00$, 132.04, 129.75, 129.49, 124.36, 111.62, 90.71, 55.95. Molecular formula $\mathrm{C}_{18} \mathrm{H}_{17} \mathrm{BrO}_{4}$ (HRMS) Calculated $=377.2291$, Observed $=377.0370$.

2.1.3. (E)-3-(4-fluorophenyl)-1-(2,4,6-trimethoxyphenyl)prop-2-en-1-one (CH3)

M.P: $110-112{ }^{\circ} \mathrm{C} ;{ }^{1} \mathrm{H}$ NMR $\left(500 \mathrm{MHz}, \mathrm{CDCl}_{3}\right)$ 8: 3.76-3.71 (s, 6H, Ar-2 ${ }^{\prime} \mathrm{OCH}_{3}$, Ar$\left.6^{\prime} \mathrm{OCH}_{3}\right), 3.86-3.82\left(\mathrm{~s}, 3 \mathrm{H}, \mathrm{Ar}-4^{\prime} \mathrm{OCH}_{3}\right), 6.16\left(\mathrm{~s}, 2 \mathrm{H}, \mathrm{Ar}-3^{\prime} \mathrm{C} \underline{\mathrm{H}}, \mathrm{Ar}-5^{\prime} \mathrm{C} \underline{\mathrm{H}}\right), 6.90-6.93(1 \mathrm{H}$, $\left.\mathrm{d}, J=15.0 \mathrm{~Hz},-\mathrm{CH}_{\alpha}\right), 7.35-7.32\left(1 \mathrm{H}, \mathrm{d}, J=15.0 \mathrm{~Hz},-\mathrm{CH}_{\beta}\right), 7.03-7.07(2 \mathrm{H}, \mathrm{d}, \mathrm{Ar}-3 \mathrm{C} \underline{\mathrm{H}}$, 


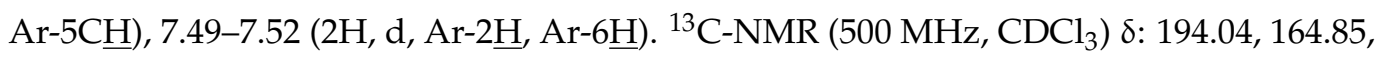
$161.40,158.74,144.32,142.72,131.28,130.12,127.00,115.87,90.71,55.49$. Molecular formula $\mathrm{C}_{18} \mathrm{H}_{17} \mathrm{FO}_{4}$ (HRMS) Calculated $=316.3235$, Observed $=317.1219$.

2.1.4. (E)-3-(4-chlorophenyl)-1-(2,3,4-trimethoxyphenyl)prop-2-en-1-one (CH4)

M.P: ${ }_{108}-110{ }^{\circ} \mathrm{C} ;{ }^{1} \mathrm{H}$ NMR $\left(500 \mathrm{MHz}, \mathrm{CDCl}_{3}\right) \delta: 3.92$ (s, 9H, $\mathrm{Ar}-2^{\prime} \mathrm{OCH}_{3}, \mathrm{Ar}-3^{\prime} \mathrm{OCH}_{3}$, Ar-4 $\left.{ }^{\prime} \mathrm{OCH}_{3}\right), 6.76\left(\mathrm{~d}, \mathrm{Ar}-5^{\prime} \mathrm{CH}\right), 7.38-7.36(\mathrm{~d}, 2 \mathrm{H}, \mathrm{Ar}-3 \mathrm{H}, \mathrm{Ar}-5 \underline{\mathrm{H}}), 7.55-7.53(\mathrm{~d}, 2 \mathrm{H}, \mathrm{Ar}-2 \mathrm{H}$, Ar-6ㅂ) $), 7.51\left(\mathrm{Ar}-6^{\prime} \mathrm{CH}\right), 7.50-7.47\left(1 \mathrm{H}, \mathrm{d}, J=15.0 \mathrm{~Hz},-\mathrm{CH}_{\alpha}\right), 7.65-7.62(1 \mathrm{H}, \mathrm{d}, J=15.0 \mathrm{~Hz}$, $\left.-\mathrm{CH}_{\beta}\right) .{ }^{13} \mathrm{C}-\mathrm{NMR}\left(500 \mathrm{MHz}, \mathrm{CDCl}_{3}\right) \delta: 190.56,157.26,153.87,142.14,141.37,136.04$, $133.72,129.53,129.18,127.00,126.56,125.97,107.41,62.17,61.12,56.16$. Molecular formula $\mathrm{C}_{18} \mathrm{H}_{17} \mathrm{ClO}_{4}$ (HRMS) Calculated $=332.7781$, Observed $=333.0892$. Molecular formula $\mathrm{C}_{18} \mathrm{H}_{17} \mathrm{ClO}_{4}$ (HRMS) Calculated $=332.7781$, Observed $=333.0892$.

\subsection{5. (E)-3-(4-bromophenyl)-1-(2,3,4-trimethoxyphenyl)prop-2-en-1-one (CH5)}

M.P: $98-100{ }^{\circ} \mathrm{C} ;{ }^{1} \mathrm{H}$ NMR $\left(500 \mathrm{MHz}, \mathrm{CDCl}_{3}\right)$ 8: 3.92 (s, 9H, $\mathrm{Ar}-2^{\prime} \mathrm{OCH}_{3}, \mathrm{Ar}^{\prime} \mathrm{O}^{\prime} \mathrm{OCH}_{3}$, Ar-4' $\left.\mathrm{OCH}_{3}\right), 6.75\left(\mathrm{~d}, 1 \mathrm{H}, \mathrm{Ar}-5^{\prime} \mathrm{CH}\right), 7.38-7.36(\mathrm{~d}, 2 \mathrm{H}, \mathrm{Ar}-3 \underline{\mathrm{H}}, \mathrm{Ar}-5 \underline{\mathrm{H}}), 7.55-7.53(\mathrm{~d}, 2 \mathrm{H}, \mathrm{Ar}-2 \underline{\mathrm{H}}$ Ar-6H), 7.51-7.47 (1H, Ar-6 $\left.6^{\prime} \overline{\mathrm{H}}\right), 7.51-7.48\left(1 \mathrm{H}, \mathrm{d}, J=15.0 \mathrm{~Hz},-\mathrm{CH}_{\alpha}\right), 7.65-7.62(1 \mathrm{H}, \mathrm{d}$, $\left.J=15.0 \mathrm{~Hz},-\mathrm{CH}_{\beta}\right){ }^{13} \mathrm{C}-\mathrm{NMR}\left(500 \mathrm{MHz}, \mathrm{CDCl}_{3}\right) \delta: 190.50,157.25,153.87,142.14,141.34$, 136.04, 133.71, 129.53, 129.19, 126.99, 126.56, 125.97, 107.41, 62.17, 61.12, 56.17. Molecular formula $\mathrm{C}_{18} \mathrm{H}_{17} \mathrm{BrO}_{4}$ (HRMS) Calculated $=377.2291$, Observed $=377.0370$.

2.1.6. (E)-3-(4-fluorophenyl)-1-(2,3,4-trimethoxyphenyl)prop-2-en-1-one (CH6)

M.P: 80-82 ${ }^{\circ} \mathrm{C} ;{ }^{1} \mathrm{H}$ NMR $\left(500 \mathrm{MHz}, \mathrm{CDCl}_{3}\right)$ 8: 3.92 (s, 9H, $\mathrm{Ar}-2^{\prime} \mathrm{OCH}_{3}, \mathrm{Ar}^{\prime} 3^{\prime} \mathrm{OCH}_{3}$, $\left.\mathrm{Ar}-4^{\prime} \mathrm{OCH}_{3}\right), 6.75\left(\mathrm{~d}, \mathrm{Ar}-5^{\prime} \mathrm{CH}\right), 7.11-7.07(\mathrm{~d}, 2 \mathrm{H}, \mathrm{Ar}-3 \underline{\mathrm{H}}, \mathrm{Ar}-5 \underline{\mathrm{H}}), 7.62-7.59(\mathrm{~d}, 2 \mathrm{H}, \mathrm{Ar}-2 \underline{\mathrm{H}}, \mathrm{Ar}-$ $6 \underline{\mathrm{H}}), 7.50\left(\mathrm{Ar}-6^{\prime} \mathrm{CH}\right), 7.45-7.42\left(1 \mathrm{H}, \mathrm{d}, J=15.0 \mathrm{~Hz},-\mathrm{CH}_{\alpha}\right), 7.67-7.64(1 \mathrm{H}, \mathrm{d}, J=15.0 \mathrm{~Hz}$, $\left.-\mathrm{CH}_{\beta}\right) .{ }^{13} \mathrm{C}-\mathrm{NMR}\left(500 \mathrm{MHz}, \mathrm{CDCl}_{3}\right) \delta: 190.63,157.15,153.81,142.14,141.67,131.44$, $131.42,130.28,130.21,126.66,126.29,125.91,107.41,62.17,61.12$, 56.17. Molecular formula $\mathrm{C}_{18} \mathrm{H}_{17} \mathrm{FO}_{4}$ (HRMS) Calculated $=316.3235$, Observed $=317.1219$.

\subsection{MAOs and BACE1 Inhibition Studies}

MAO events were assessed with recombinant MAO-A and MAO-B, as well as the substrates kynuramine $(0.06 \mathrm{mM})$ and benzylamine $(0.3 \mathrm{mM})$. The kinetics of MAO-B were analyzed under $2.4 \times \mathrm{K}_{\mathrm{m}}$ (i.e., $0.051 \mathrm{mM}$ ) of benzylamine. BACE- 1 was measured using a $\beta$-secretase (BACE-1) assay kit at $320 \mathrm{~nm}$ for excitation and $405 \mathrm{~nm}$ for emission using a fluorescence spectrometer. The inhibitory activities of $\mathrm{CH} 1-\mathrm{CH} 6$ against MAO-A, MAO-B and BACE- 1 were observed at $10 \mu \mathrm{M}$. $\mathrm{IC}_{50}$ values of $\mathrm{CH} 4$ and $\mathrm{CH} 5$, which showed residual activities of $<50 \%$ for MAO-A and MAO-B, were evaluated, as described previously. The $\mathrm{IC}_{50}$ value of $\mathrm{CH} 5$ for BACE- 1 was also analyzed $[55,56]$.

\subsection{Enzyme Inhibition and Kinetic Studies}

The inhibitory actions of the six molecules against MAO-A, MAO-B, and BACE-1 were first tested at $10 \mu \mathrm{M}$. Initially, the $\mathrm{IC}_{50}$ values of the compounds for MAOs were calculated [57]. At three inhibitory concentrations and five substrate concentrations, kinetic tests were conducted on $\mathrm{CH} 4$ and $\mathrm{CH} 5$, which inhibited MAO-B most potently.

\subsection{Inhibitor Reversibility Analysis}

Dialysis was used to assess the reversibility of MAO-B inhibitions by $\mathrm{CH} 4$ and $\mathrm{CH} 5$ after preincubating them for $30 \mathrm{~min}$ at $0.15 \mu \mathrm{M}$ with MAO-B. For contrast, MAO-B was preincubated with lazabemide (a reference reversible MAO-B inhibitor) or pargyline (a reference irreversible MAO-B inhibitor) at 0.20 and $0.30 \mu \mathrm{M}$. Reversibility patterns were analyzed by comparing the activities of dialyzed $\left(A_{D}\right)$ and undialyzed $\left(A_{U}\right)$ samples [58]. 


\subsection{Cytotoxicity and ROS Assay}

The lead molecules $\mathrm{CH} 4$ and $\mathrm{CH} 5$ in the current series were further evaluated for their cytotoxic nature and ROS scavenging ability by the previously reported procedure $[59,60]$ (Supplementary Material).

\subsection{Blood-Brain Barrier (BBB) Permeability}

The CNS bioavailability of the molecules was confirmed by a parallel artificial membrane permeability assay (PAMPA) by Di et al. [61].

\subsection{Computational Studies}

X-ray coordinates of the crystal structures of both the MAO isoforms and BACE-1 were retrieved from the Protein Data Bank with the entries 2Z5X, 2V5Z and 3TPP, respectively [62-64]. Protein and ligand structures were treated with the Protein Preparation Wizard and Ligprep Tool, respectively [65-67]. These preliminary steps are crucial for further docking analyses, allowing the generation of the correct protonation states at physiological $\mathrm{pH}$ or the generation of all allowed tautomers and possible conformations. Enclosing boxes were centered on the center of a mass of cognate ligand, and SP docking protocols were employed using GLIDE software [68]. To corroborate the reliability of docking simulations, redocking analyses were performed on the cognate ligands in their binding sites. Cognate ligands were moved back to the original positions with Root Mean Square Deviations (RMSD), considering all the heavy atoms, equal to $0.155 \AA, 0.208 \AA$, and $0.467 \AA$ for BACE-1, MAO-A, and MAO-B cognate ligands, respectively. Discovery Studio 2.5 software package (Accelrys, San Diego, CA, USA) was used to predict the ADMET parameters of all the molecules. The Vega and PredHerg platforms were employed to assess the mutagenicity and cardiotoxicity potentials [69,70].

\section{Results}

\subsection{Synthesis}

The synthesis of two small series of trimethoxylated halogenated chalcones was achieved by the Claisen-Schmidt condensation of 2,4,6-trimethoxy acetophenone/2,3,4trimethoxy acetophenone with various para-substituted halogenated benzaldehydes. ${ }^{1} \mathrm{H}$ NMR showed a sharp doublet peak for $\mathrm{H} \alpha$ and $\mathrm{H} \beta$ at 7.65-7.62 and 7.50-7.47, respectively. A large coupling constant of $15 \mathrm{~Hz}$ of the double bond of chalcones revealed its trans conformation [71]. The protons of methoxy groups showed a singlet peak at 3.92, while the ${ }^{13} \mathrm{C}$ NMR showed a peak at 55.95-62.17 for the methoxy carbon and a characteristic peak of carbonyl carbon at 190.63-193.91. The HRMS analysis showed the molecular weight of the targeted compounds [Supplementary Material].

\subsection{MAO-A, MAO-B, and BACE1 Inhibition Studies}

The six compounds $\mathrm{CH} 1-\mathrm{CH} 6$ inhibited MAO-B more effectively than MAO-A, and $\mathrm{CH} 4$ and $\mathrm{CH} 5$ revealed the most inhibitory activities against MAO-A and MAO-B at $10 \mu \mathrm{M}$ with residual activities of $<50 \%$ (Table 1 ). Compound $\mathrm{CH} 5$ most potently inhibited MAO-A with an $\mathrm{IC}_{50}$ value of $0.46 \mu \mathrm{M}$, followed by $\mathrm{CH} 4\left(\mathrm{IC}_{50}=0.84 \mu \mathrm{M}\right)$. In the compounds, $2^{\prime}, 3^{\prime}, 4^{\prime}$-methoxy moiety in CH4-CH6 was more effective for MAO-B inhibition than $2^{\prime}, 4^{\prime}, 6^{\prime}$ methoxy moiety in $\mathrm{CH} 1-\mathrm{CH} 3$. In $2^{\prime}, 3^{\prime}, 4^{\prime}$-methoxy derivatives $(\mathrm{CH} 4-\mathrm{CH} 6)$, inhibitory activities against MAO-B increased in the order of $-\mathrm{Br}$ in $\mathrm{CH} 5>-\mathrm{Cl}$ in $\mathrm{CH} 4>-\mathrm{F}$ in $\mathrm{CH} 6$ at para-position in ring $\mathrm{B}$. $\mathrm{CH} 5$ and $\mathrm{CH} 4$ were selective for MAO-B with selectivity index (SI) values of 31.3 and 15.1, respectively, over MAO-A. No compounds effectively inhibited BACE-1, except $\mathrm{CH} 4$ and $\mathrm{CH} 5$, which moderately inhibited BACE- 1 with $\mathrm{IC}_{50}$ values of 13.6 and $19.8 \mu \mathrm{M}$, respectively (Table 1$)$. The $\mathrm{IC}_{50}$ value of $\mathrm{CH} 4$ for BACE-1 $(13.6 \mu \mathrm{M})$ was similar to that of reference quercetin $\left(\mathrm{IC}_{50}=13.4 \mu \mathrm{M}\right)$

Based upon the above small selected library of compounds, it is possible to expand some interesting structure-activity relationships (SARs) on the basis of the orientation pattern of methoxyl groups on the various positions of phenyl ring $\mathbf{A}$ and the presence of 
various halogens on the para-position of ring $\mathbf{B}$ of chalcones. The results clearly documented that all the trimethoxylated halogenated derivatives showed moderate to good inhibition of MAO-B as compared to MAO-A. Considering the orientation pattern, it is clearly understood that introduction of methoxyl groups on the $2^{\prime}, 4^{\prime}$, and $6^{\prime}$ positions does not have much influence when compared with the positions of $2^{\prime}, 3^{\prime}$, and $4^{\prime}$. This suggests that the crowding of methoxyl groups without the separation of a carbon atom on the $\mathbf{A}$ ring is crucial for the activity. As regards halogen substitution on the $\mathbf{B}$ ring, bromine or chlorine improved MAO-B inhibitory activity when compared to fluorine substitution (the residual activities were $0.93 \%$ and $0.38 \%$ at $10.0 \mu \mathrm{M}$, respectively).

Table 1. Inhibitions of MAO-A, MAO-B, AChE, BChE, and BACE-1 by halogenated trimethoxy chalcone derivatives ${ }^{\text {a }}$.

\begin{tabular}{|c|c|c|c|c|c|c|c|c|c|}
\hline \multirow{2}{*}{ Compounds } & \multicolumn{5}{|c|}{ Residual Activity (\%) } & \multicolumn{3}{|c|}{$\mathrm{IC}_{50}(\mu \mathrm{M})$} & \multirow[t]{2}{*}{$\mathrm{SI}^{b}$} \\
\hline & MAO-A & MAO-B & AChE & BChE & BACE-1 & MAO-A & MAO-B & BACE-1 & \\
\hline $\mathrm{CH} 1$ & $90.1 \pm 7.51$ & $70.7 \pm 2.16$ & $89.2 \pm 2.23$ & $71.1 \pm 0.68$ & $61.3 \pm 0.078$ & & & & \\
\hline $\mathrm{CH} 2$ & $92.4 \pm 1.10$ & $84.3 \pm 3.00$ & $83.8 \pm 7.96$ & $74.5 \pm 0.71$ & $57.2 \pm 0.46$ & & & & \\
\hline $\mathrm{CH} 3$ & $94.9 \pm 7.19$ & $75.4 \pm 0.27$ & $75.2 \pm 3.43$ & $79.9 \pm 0.76$ & $59.7 \pm 0.077$ & & & & \\
\hline $\mathrm{CH} 4$ & $63.7 \pm 1.02$ & $0.93 \pm 0.25$ & $72.5 \pm 7.22$ & $73.8 \pm 0.70$ & $54.3 \pm 2.20$ & $12.7 \pm 0.23$ & $0.84 \pm 0.025$ & $13.6 \pm 0.094$ & 15.1 \\
\hline $\mathrm{CH} 5$ & $66.7 \pm 3.96$ & $0.38 \pm 0.53$ & $81.5 \pm 5.31$ & $67.1 \pm 0.64$ & $64.3 \pm 0.74$ & $14.4 \pm 1.10$ & $0.46 \pm 0.12$ & $19.8 \pm 0.12$ & 31.3 \\
\hline $\mathrm{CH} 6$ & $92.1 \pm 0.75$ & $19.6 \pm 2.17$ & $83.2 \pm 1.23$ & $84.6 \pm 0.80$ & $66.7 \pm 0.45$ & & $4.17 \pm 0.23$ & & \\
\hline Toloxatone & & & & & & $1.08 \pm 0.025$ & - & - & \\
\hline Lazabemide & & & & & & - & $0.11 \pm 0.016$ & - & \\
\hline Clorgyline & & & & & & $0.007 \pm 0.0007$ & - & - & \\
\hline Pargyline & & & & & & - & $0.14 \pm 0.0059$ & - & \\
\hline Quercetin & & & & & & - & - & $13.4 \pm 0.035$ & \\
\hline
\end{tabular}

${ }^{\mathrm{a}}$ Results are the means \pm standard errors of duplicate or triplicate experiments. ${ }^{\mathrm{b}}$ Selectivity index (SI) values are expressed for MAO-B as compared with MAO-A. IC 50 values of donepezil for $\mathrm{AChE}$ and $\mathrm{BChE}$ were $0.0095 \pm 0.0019$ and $0.18 \pm 0.0038 \mu \mathrm{M}$, respectively. Values for reference compounds were determined after preincubation with enzymes for $30 \mathrm{~min}$.3.3. Kinetic Study.

The two representative MAO-B inhibitors, $\mathrm{CH} 4$ and $\mathrm{CH} 5$, showed good BACE-1 inhibition with $54.3 \%$ and $64.3 \%$ residual activity, respectively, at $10.0 \mu \mathrm{M}$. The $\mathrm{IC}_{50}$ value of the BACE-1 inhibition of $\mathrm{CH} 4$ was $13.6 \mu \mathrm{M}$, which, interestingly, is very close to the standard value. In BACE-1 inhibition, both chlorine and bromine have a large impact on the fluorine substitution

\subsection{Kinetic Study}

Kinetic experiments were carried out at five concentrations of the substrates and three inhibitor concentrations. In the kinetic studies of MAO-B binding by $\mathrm{CH} 4$ and $\mathrm{CH} 5$, Lineweaver-Burk plots showed that $\mathrm{CH} 4$ and $\mathrm{CH} 5$ were competitive inhibitors of MAO-B (Figure $1 \mathrm{a}, \mathrm{c}$ ), and their secondary plots showed that their $\mathrm{K}_{\mathrm{i}}$ values were $0.68 \pm 0.17$ and $0.31 \pm 0.014 \mu \mathrm{M}$, respectively (Figure $1 \mathrm{~b}, \mathrm{~d}$ ). These results suggest that $\mathrm{CH} 4$ and $\mathrm{CH} 5$ compete with the substrate at the active site of MAO-B.

\subsection{Reversibility Studies}

The reversibilities of the inhibitions were analyzed using dialysis after preincubating MAO-B with $\mathrm{CH} 4$ or $\mathrm{CH} 5$ for $30 \mathrm{~min}$, as previously described. In the experiments, the concentrations used were the following: $\mathrm{CH} 4$ at $1.68 \mu \mathrm{M}, \mathrm{CH} 5$ at $0.92 \mu \mathrm{M}$, lazabemide (a reference reversible inhibitor) at $0.22 \mu \mathrm{M}$, and pargyline (a reference irreversible inhibitor) at $0.28 \mu \mathrm{M}$. The relative activities for undialyzed $\left(\mathrm{A}_{U}\right)$ and dialyzed $\left(\mathrm{A}_{\mathrm{D}}\right)$ samples were compared to determine the reversibility patterns. In reversibility experiments using dialysis, the inhibition of MAO-B by $\mathrm{CH} 4$ and $\mathrm{CH} 5$ was recovered from $30.9 \%\left(\mathrm{~A}_{U}\right)$ to $96.9 \%\left(A_{D}\right)$, and from $37.2 \%$ to $73.8 \%$, respectively (Figure 2$)$. The recovery values were indistinguishable to those of the reversible reference lazabemide (from $33.0 \%$ to $89.2 \%$ ), contrary to the inhibition of MAO-B by the irreversible inhibitor pargyline, which was not recovered (i.e., from $37.2 \%$ to $38.5 \%$ ). These experiments indicated that $\mathrm{CH} 4$ and $\mathrm{CH} 5$ were reversible inhibitors of MAO-B. 


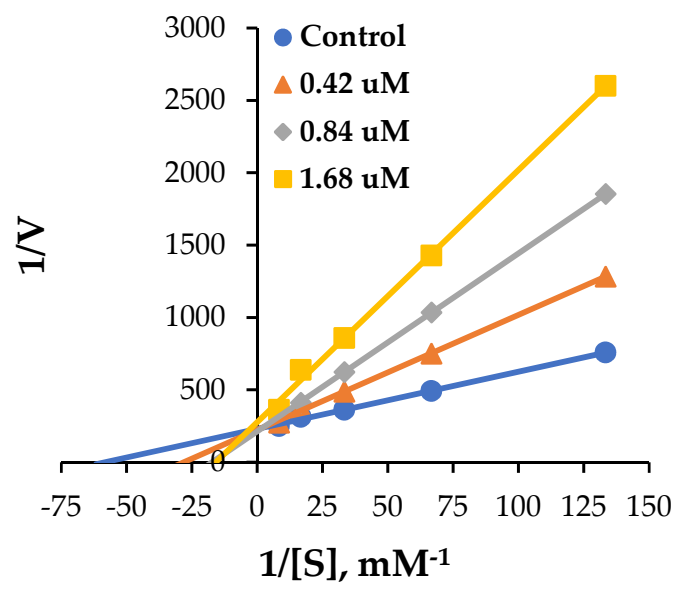

(a)

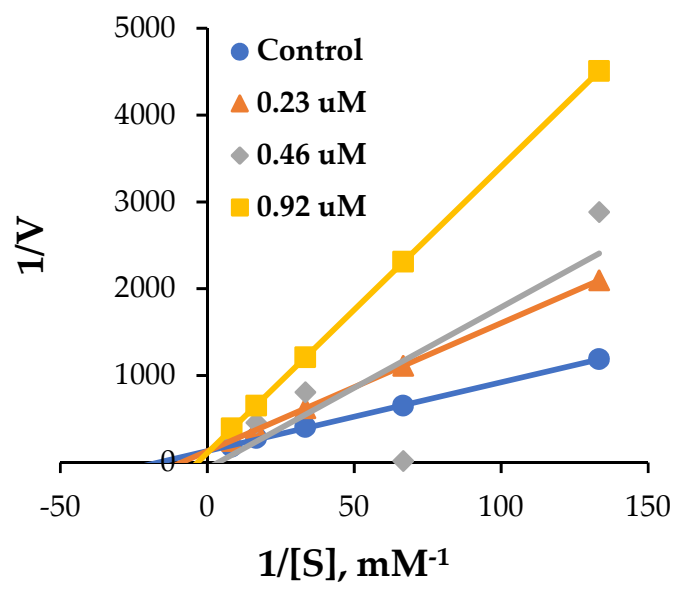

(c)

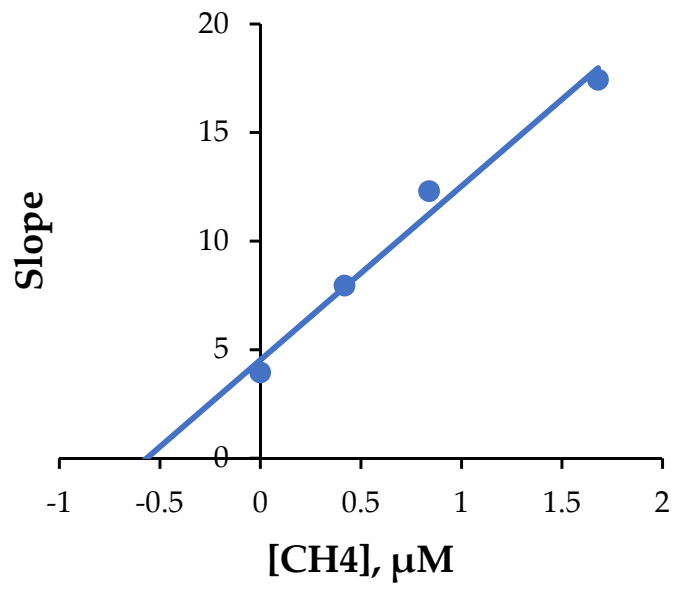

(b)

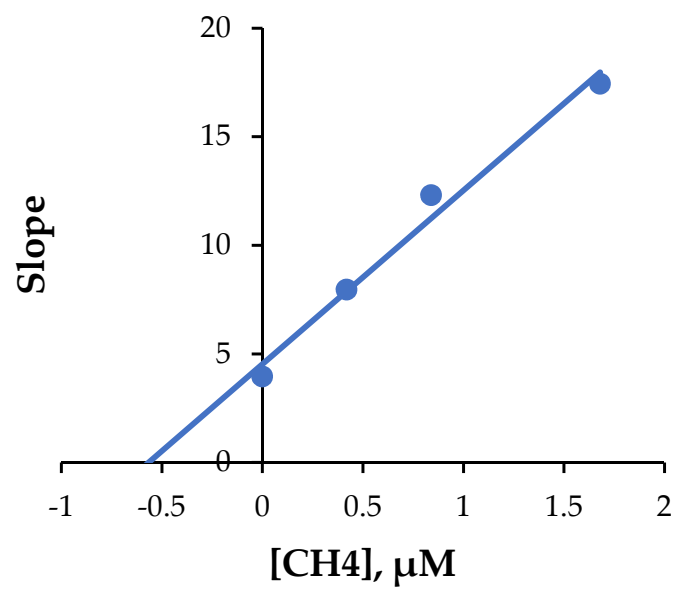

(d)

Figure 1. Lineweaver-Burk plots for MAO-B inhibition by $\mathrm{CH} 4$ and $\mathrm{CH} 5(\mathbf{a}, \mathbf{c})$, and their respective secondary plots $(\mathbf{b}, \mathbf{d})$ of the slopes vs. inhibitor concentrations.

\section{Undialyzed Dialyzed}

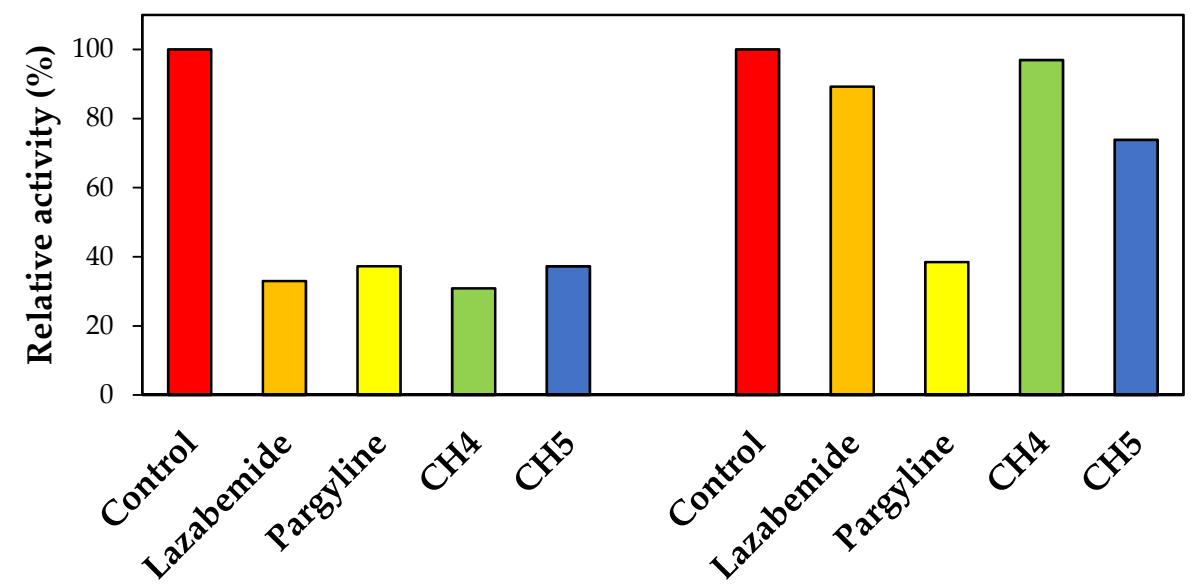

Figure 2. Recoveries of MAO-B inhibitions by $\mathrm{CH} 4$ and $\mathrm{CH} 5$ using dialysis experiments. 


\subsection{Blood-Brain Barrier (BBB) Permeation Studies}

From the assay, highly effective permeabilities and high CNS bioavailabilities were observed for the halogenated chalcones with Pe ranges of $13.22 \sim 15.65 \times 10^{-6} \mathrm{~cm} / \mathrm{s}$ (Table 2). All halogenated substituted derivatives showed higher CNS permeabilities than unsubstituted ones.

Table 2. BBB assay of the $\mathrm{CH}$ compounds.

\begin{tabular}{|c|c|c|c|}
\hline Compounds & $\begin{array}{c}\text { Bibliography } \\
\operatorname{Pe}\left(\times 10^{-6} \mathrm{~cm} / \mathrm{s}\right)^{a}\end{array}$ & $\begin{array}{c}\text { Experimental } \\
\operatorname{Pe}\left(\times 10^{-6} \mathrm{~cm} / \mathrm{s}\right)\end{array}$ & Prediction \\
\hline Progesterone & 9.3 & $9.02 \pm 0.11$ & $\mathrm{CNS}+$ \\
\hline Verapamil & 16.0 & $15.53 \pm 0.24$ & CNS+ \\
\hline Piroxicam & 2.5 & $2.43 \pm 0.30$ & $\mathrm{CNS}+1-$ \\
\hline Lomefloxacin & 1.1 & $1.12 \pm 0.01$ & CNS- \\
\hline Dopamine & 0.2 & $0.22 \pm 0.01$ & CNS- \\
\hline $\mathrm{CH} 1$ & & $13.22 \pm 0.33$ & CNS+ \\
\hline $\mathrm{CH} 2$ & & $14.06 \pm 0.80$ & CNS+ \\
\hline $\mathrm{CH} 3$ & & $15.33 \pm 0.71$ & CNS+ \\
\hline $\mathrm{CH} 4$ & & $14.56 \pm 0.26$ & $\mathrm{CNS}+$ \\
\hline $\mathrm{CH} 5$ & & $15.65 \pm 0.22$ & $\mathrm{CNS}+$ \\
\hline $\mathrm{CH} 6$ & & $15.22 \pm 0.26$ & $\mathrm{CNS}+$ \\
\hline
\end{tabular}

CNS+ (high): $\operatorname{Pe}\left(10^{-6} \mathrm{~cm} / \mathrm{s}\right)>4.00 ; \mathrm{CNS}-$ (low): $\mathrm{Pe}\left(10^{-6} \mathrm{~cm} / \mathrm{s}\right)<2.00 ; \mathrm{CNS} \pm$ (uncertain): $\mathrm{Pe}\left(10^{-6} \mathrm{~cm} / \mathrm{s}\right)$ from 4.00 to $2.00 .{ }^{\text {a }}$ from [61].

\subsection{In Vitro Toxicity Evaluation}

An in vitro toxicity evaluation of $\mathrm{CH} 4$ and $\mathrm{CH} 5$ was carried out using an MTT assay. We used the African Green Monkey kidney cell line (Vero) as a valuable in vitro model for basal toxicity studies [72]. To check the toxicity of the tested compounds, the Vero cell line was incubated with different concentrations of CH4 and CH5 (1 to $500 \mu \mathrm{g} / \mathrm{mL})$, and the relative cell viability was measured after $48 \mathrm{~h}$. Both the compounds induced toxicity at concentrations higher than $200 \mu \mathrm{g} / \mathrm{mL}$ (Figures $3 \mathrm{~A}$ and $4 \mathrm{~A}$ ). The result of the cell viability assay was represented as a dose-response curve using the GraphPad Prism 6.0 software (USA). The $\mathrm{IC}_{50}$ value was calculated at a $198.5 \mu \mathrm{g} / \mathrm{mL}$ for $\mathrm{CH} 4$ (Figure 3B) and $126.4 \mu \mathrm{g} / \mathrm{mL}$ for $\mathrm{CH} 5$ (Figure $4 \mathrm{~B}$ ). The reduction in cell number and also the membrane damage were very evident in treatment with $\mathrm{CH} 4$ and $\mathrm{CH}_{5}$ at $\mathrm{IC}_{50}$ and higher concentrations, as analyzed by phase-contrast microscope. These two experiments strongly support that $\mathrm{CH} 4$ and $\mathrm{CH} 5$ are one hundred times safer than the effective concentration of one micromolar (Figures 3C and 4C). Both results demonstrate that the undesired changes in membrane integrity and a reduction in cell number are indicative of oxidative stress only at higher concentrations.

\subsection{ROS Assay}

Our next attempt was to study the effect of $\mathrm{CH} 4$ and $\mathrm{CH} 5$ on inhibiting the excess reactive oxygen species (ROS) involved in the pathogenesis of neurodegenerative diseases. This ROS causes neuronal damage via oxidative damage in the brain during neurodegenerative diseases $[73,74]$. We examined the intracellular ROS generation on Vero cell cultures after exposure to exogenous $\mathrm{H}_{2} \mathrm{O}_{2}$. During our experiment, it was noted $\mathrm{H}_{2} \mathrm{O}_{2}$-treated Vero cells had a higher ROS generation. When we incubated Vero cells with $\mathrm{CH} 4$ and $\mathrm{CH} 5$ at $\mathrm{IC}_{50}$, we observed a decrease in ROS levels compared with non-treated cells (Figure 5a,b). Based on this observation, it is understood that the disruption of the balance between pro-oxidant and antioxidant levels can be retained by $\mathrm{CH} 4$ and $\mathrm{CH} 5$ at $\mathrm{IC}_{50}$ concentrations. 
(A)

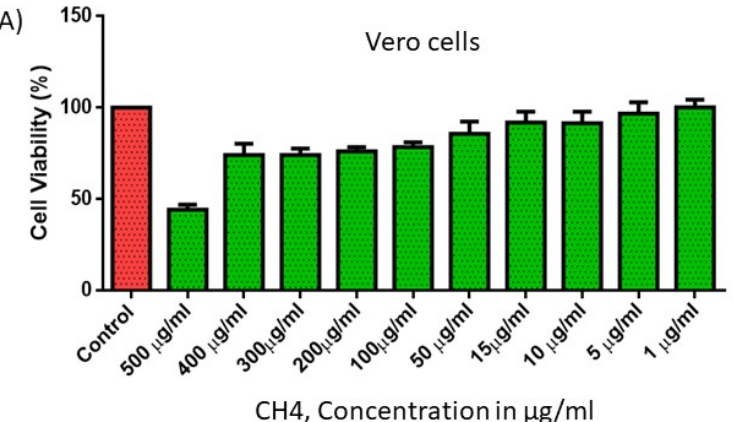

(B)

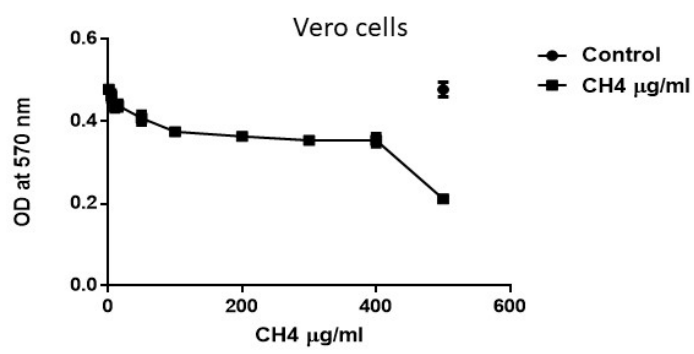

(C)
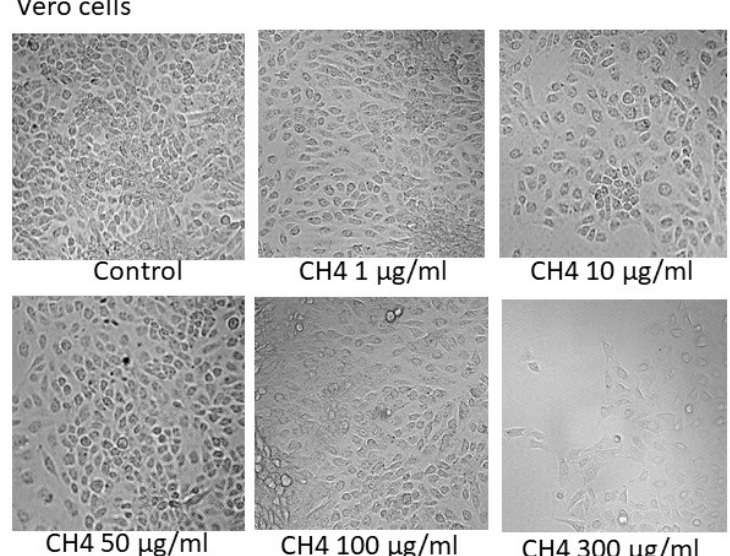

$\mathrm{CH} 4100 \mu \mathrm{g} / \mathrm{ml}$

$\mathrm{CH} 4300 \mu \mathrm{g} / \mathrm{ml}$

Figure 3. Evaluation of $\mathrm{CH} 4$ effect on cell viability in Vero cell line. (A) Cell viability; a very high percentage of viable cells (>90\%) up to $200 \mu \mathrm{g} / \mathrm{mL}$. (B) Representation of a dose-response curve and $\mathrm{IC}_{50} ; 198.5 \mu \mathrm{g} / \mathrm{mL}$ according to GraphPad Prism 6.0 software (USA). (C) Morphological observation of Vero cells in treatment with different concentrations under phase-contrast microscope. Vero cells were incubated with $\mathrm{CH} 4$ for $48 \mathrm{~h}$, and cell viability was calculated by MTT assay as described in "Experimental Procedures." Untreated cells (control) were considered to have 100\% viability.

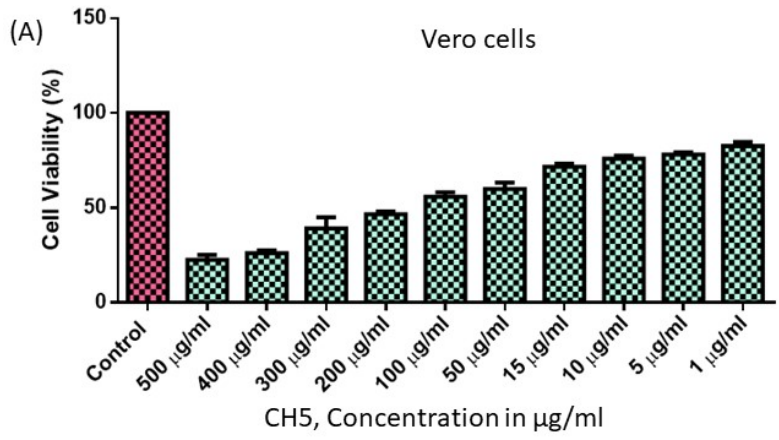

(B)
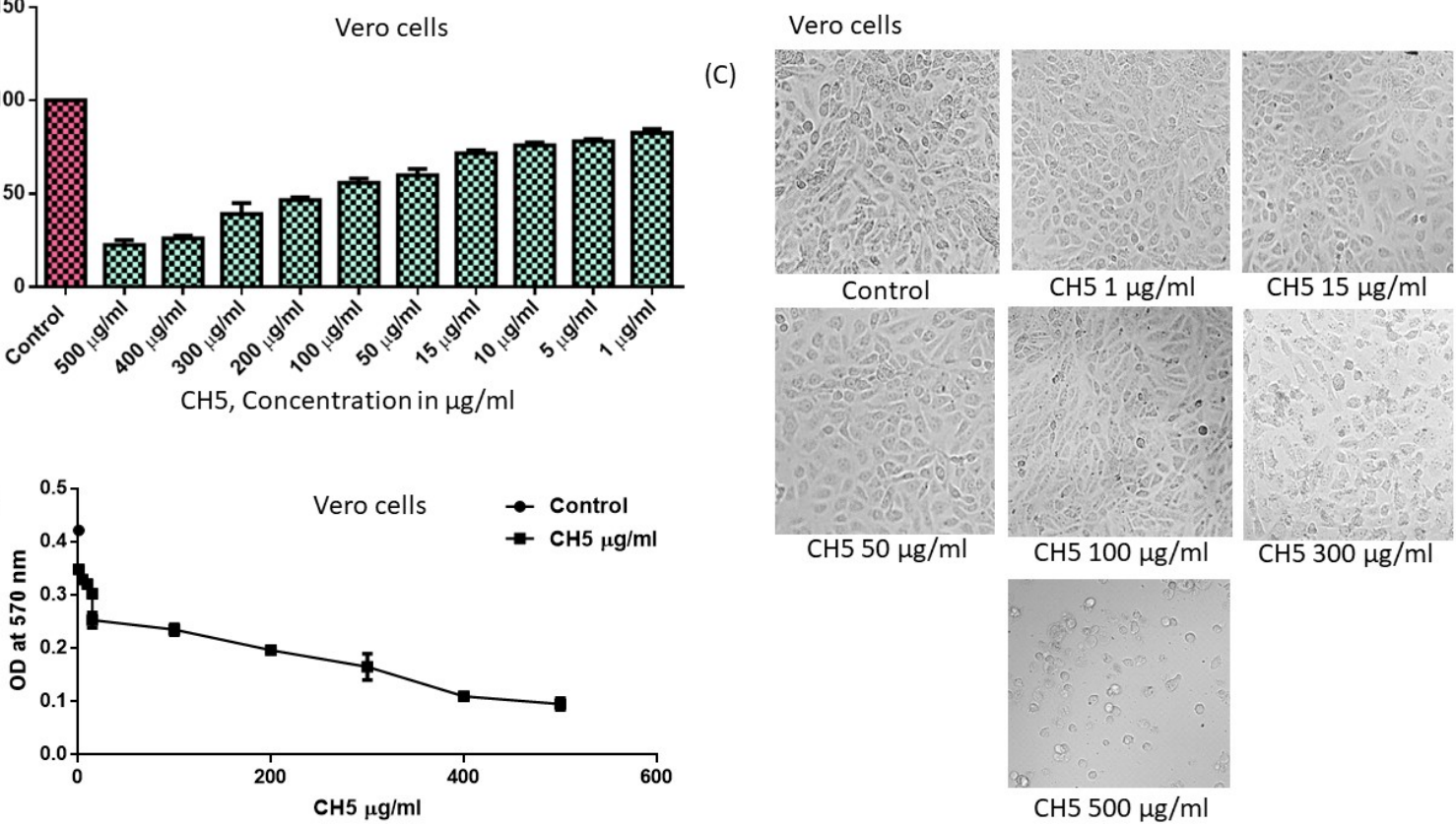

Figure 4. Evaluation of $\mathrm{CH} 5$ effect on cell viability in Vero cell line. (A) Cell viability; a very high percentage of viable cells (>90\%) up to 100 times the effective concentration. (B) Representation of a dose-response curve and $\mathrm{IC}_{50} ; 126.4 \mu \mathrm{g} / \mathrm{mL}$. (C) Morphological observation of Vero cells on treatment with different concentration under phase-contrast microscope. Vero cells were incubated with $\mathrm{CH} 5$ for $48 \mathrm{~h}$, and cell viability was calculated by MTT assay as described in "Experimental Procedures." Untreated cells (control) were considered to have 100\% viability. 
(a)

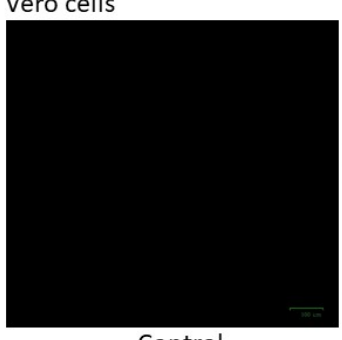

Control

Vero cells

(b)

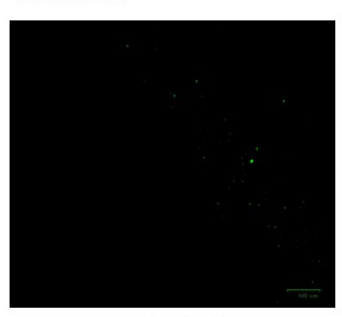

Control

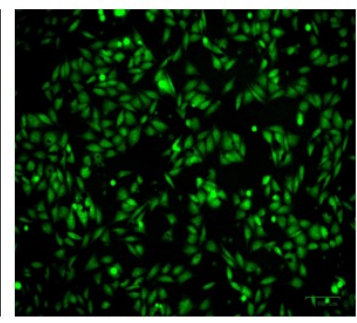

Cells treated with $\mathrm{H}_{2} \mathrm{O}_{2}$

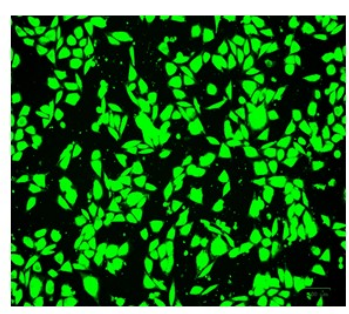

Cells treated with $\mathrm{H}_{2} \mathrm{O}_{2}$

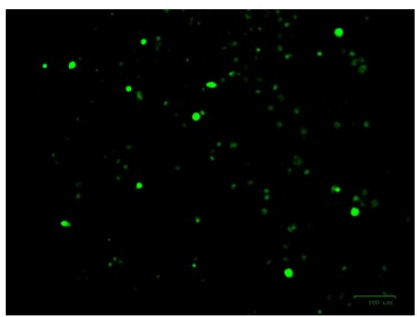

Pre-treatment ( $24 \mathrm{~h}$ ) with $\mathrm{IC}_{50}$ conc. $\mathrm{CH} 4(198.5 \mu \mathrm{g} / \mathrm{ml})+\mathrm{H}_{2} \mathrm{O}_{2}$ treatment (10 mins)

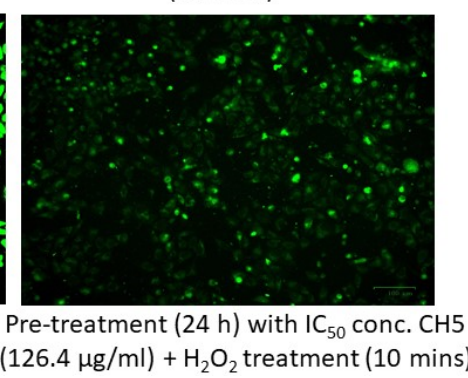

Figure 5. Effects of $\mathrm{CH} 4(\mathbf{a})$ and $\mathrm{CH} 5$ (b) on Vero cells treated with $\mathrm{H}_{2} \mathrm{O}_{2}$ to induce ROS. Vero cells were treated with $100 \mu \mathrm{g} / \mathrm{mL}$ of $30 \% \mathrm{H}_{2} \mathrm{O}_{2}$, and the production of ROS was evaluated immediately as described in "Experimental Procedures".

\subsection{Computational Studies}

Compounds $\mathrm{CH} 5$ and $\mathrm{CH} 4$ can bind the MAO-A binding pocket with similar posing (Figure 6). The para-bromine and para-fluorine styrene can establish Pi-Pi interactions with F208, and tri-methoxy phenyl rings can cause Pi-Pi interaction with Y407, facing FAD. Docking score values were equal to $-6.416 \mathrm{kcal} / \mathrm{mol}$ and $-6.465 \mathrm{kcal} / \mathrm{mol}$ for $\mathrm{CH} 5$ and $\mathrm{CH} 4$, respectively. As far as MAO-B is concerned, the para-bromine and parafluorine styrene can interact with the MAO-B-selective residue Y326, and trimethoxy phenyl rings face the FAD cofactor, forming $\mathrm{Pi}-\mathrm{Pi}$ interactions with the side chain of the Y398 aromatic residue (Figure 7). Docking score values were equal to $-9.824 \mathrm{kcal} / \mathrm{mol}$ and $-10.251 \mathrm{kcal} / \mathrm{mol}$ for $\mathrm{CH} 5$ and $\mathrm{CH} 4$, respectively. As far as BACE-1 is concerned, compounds $\mathrm{CH} 5$ and $\mathrm{CH} 4$ can establish mainly hydrophobic interactions. In particular, the tri-methoxy aromatic rings can face a hydrophobic region made by side chains of F108 and I118, and the halogenated styrene moieties take place towards Y14 side chain (Figure 8). Docking score values were equal to $-6.749 \mathrm{kcal} / \mathrm{mol}$ and $-6.762 \mathrm{kcal} / \mathrm{mol}$ for $\mathrm{CH} 5$ and $\mathrm{CH} 4$, respectively.

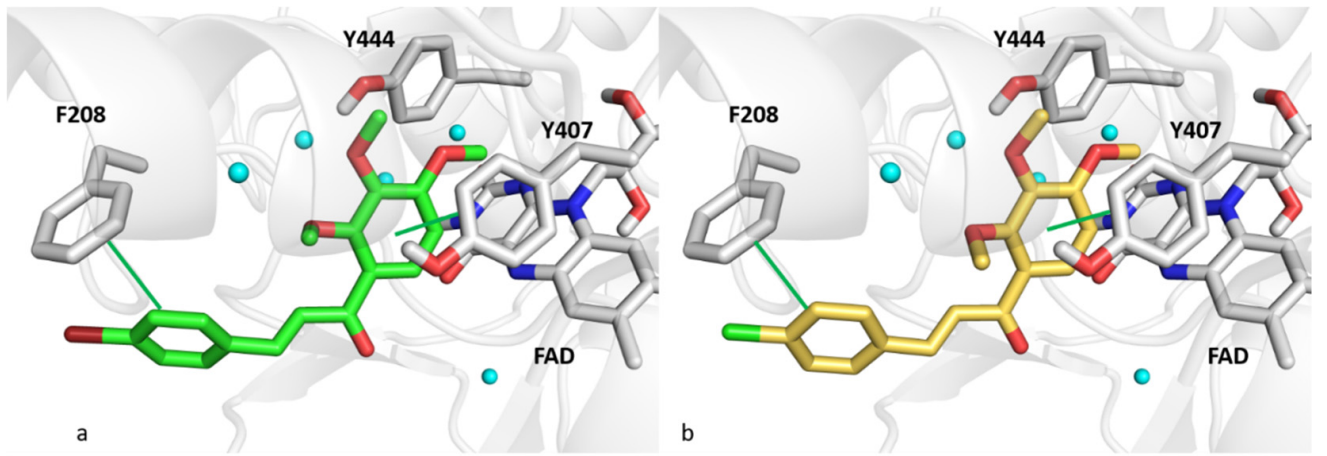

Figure 6. Zoomed in view of an MAO-A binding pocket. Panels $(\mathbf{a}, \mathbf{b})$ reported the best pose returned from docking analysis for $\mathrm{CH} 5$ (green sticks) and $\mathrm{CH} 4$ (yellow sticks), respectively. Cyan spheres indicate water molecules. Green lines show Pi-Pi contacts. 


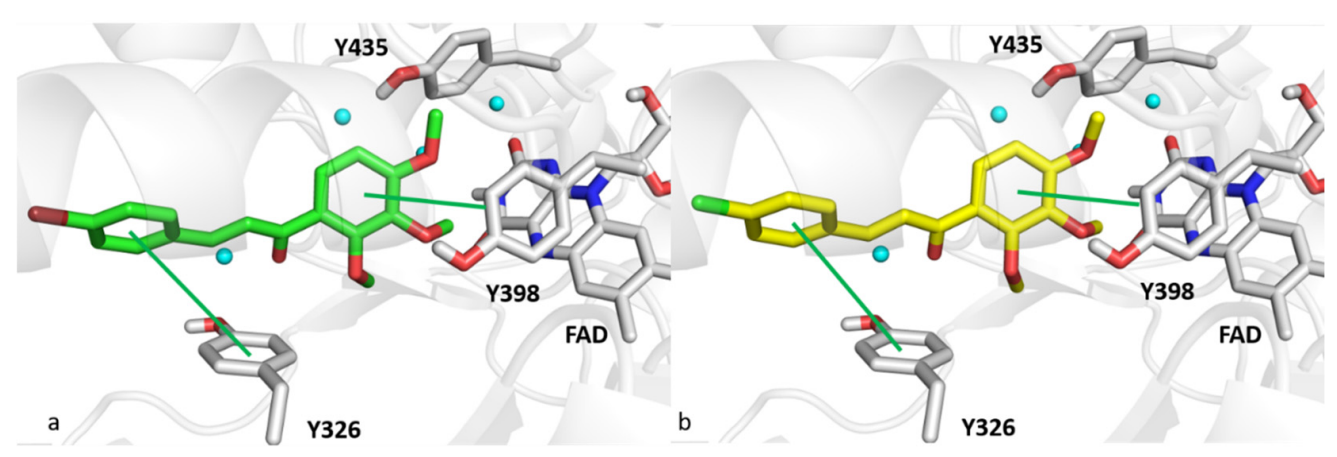

Figure 7. Zoomed in view of an MAO-B binding pocket. Panels $(\mathbf{a}, \mathbf{b})$ reported the best pose returned from docking analysis for $\mathrm{CH} 5$ (green sticks) and $\mathrm{CH} 4$ (yellow sticks), respectively. Cyan spheres indicate water molecules. Green lines show Pi-Pi contacts.
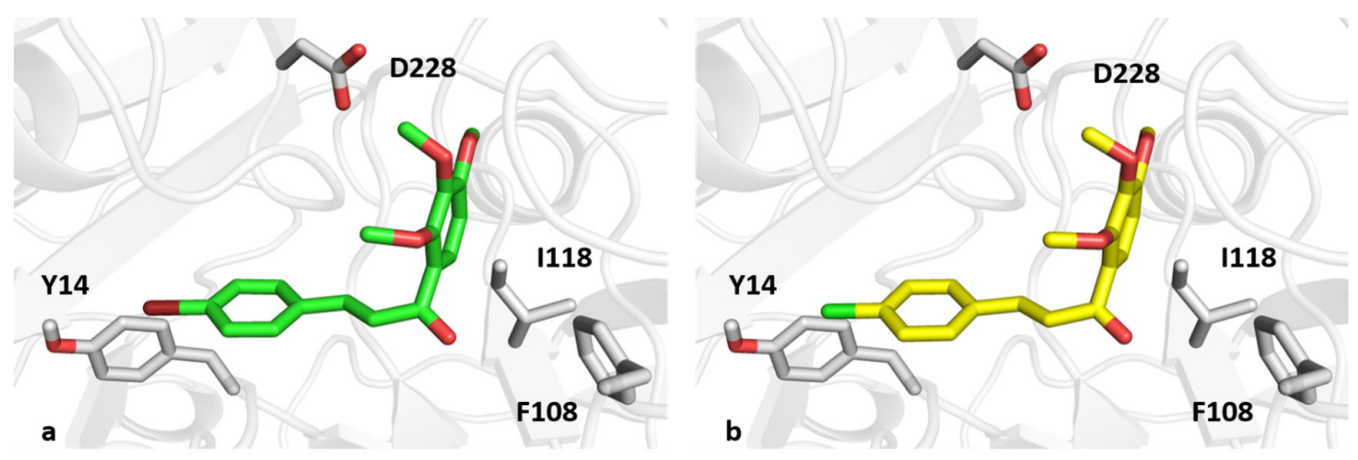

Figure 8. Zoomed in view of a BACE-1 binding pocket. Panels $(\mathbf{a}, \mathbf{b})$ reported the best pose returned from docking analysis for $\mathrm{CH} 5$ (green sticks) and $\mathrm{CH} 4$ (yellow sticks), respectively.

Computational analyses were performed in order to shed light on the interactions behind the higher affinity towards MAO-B. The interaction between $\mathrm{CH} 5$ and $\mathrm{CH} 4$ with Y326 MAO-B selective residue is crucial for enhancing activity and selectivity towards MAO-B. Furthermore, despite the binding poses of the two compounds being similar between $\mathrm{MAO}$ binding pockets, the gap between the docking score values towards the two receptors significantly favors $\mathrm{MAO}-\mathrm{B}$. For this reason, a more detailed analysis of the terms that constitute the GLIDE scoring function was performed, revealing that the Glide energy term values, which are a sum of van der Waals and Coulomb energy terms, were equal to $-50.263 \mathrm{kcal} / \mathrm{mol}$ and $-46.128 \mathrm{kcal} / \mathrm{mol}$ for $\mathrm{CH} 4$ and $\mathrm{CH} 5$ bonded to MAO-B, respectively, and $-21.341 \mathrm{kcal} / \mathrm{mol}$ and $-23.449 \mathrm{kcal} / \mathrm{mol}$ for $\mathrm{CH} 5$ and $\mathrm{CH} 4$ bonded to MAO-A, respectively, thus considerably favoring the binding to MAO-B. Regarding computational simulations of BACE-1, the binding was mainly due to hydrophobic interactions and the Glide energy term values were equal to $-46.583 \mathrm{kcal} / \mathrm{mol}$ and $-45.809 \mathrm{kcal} / \mathrm{mol}$, thus comparable to those of MAO-B.

On the basis of ADME prediction, all the compounds in the present study showed good absorption and BBB permeability, at 99\% and 95\%, respectively (Figure 9). A drug target matching analysis was also performed by using our predictive platform MuSSel (Multifingerprint Similarity Search aLgorithm) [75,76]. It is notable that MAO-A and MAO-B were predicted as reliable targets for $\mathrm{CH} 4$ and $\mathrm{CH} 5$ [Supplementary Material].

Finally, we predicted the mutagenicity and cardiotoxicity potentials for $\mathrm{CH} 4$ and CH5 [77]. These are two relevant toxicity endpoints of the utmost importance to prioritize compounds in early stages of drug discovery and are often behind the attrition of preclinical and clinical studies [78,79]. Regarding the mutagenicity, four non-test predictive models (i.e., CAESAR model version 2.1.13; SARpy / IRFMN model version 1.0.7; ISS model version 1.0.2; KNN/read-across model version 1.0.0) were employed in consensus to provide a qualitative assessment of the mutagenic potentials of $\mathrm{CH} 4$ and $\mathrm{CH} 5$ [80]. Interestingly, both 
the compounds were found to be non-mutagenic [Supplementary Materials]. Predictive QSAR models of hERG blockage were employed for cardiotoxicity analysis [81]. In the results, $\mathrm{CH} 4$ was returned to be non-cardiotoxic, while $\mathrm{CH} 5$ was flagged as potentially weak cardiotoxic (Supplementary Materials).

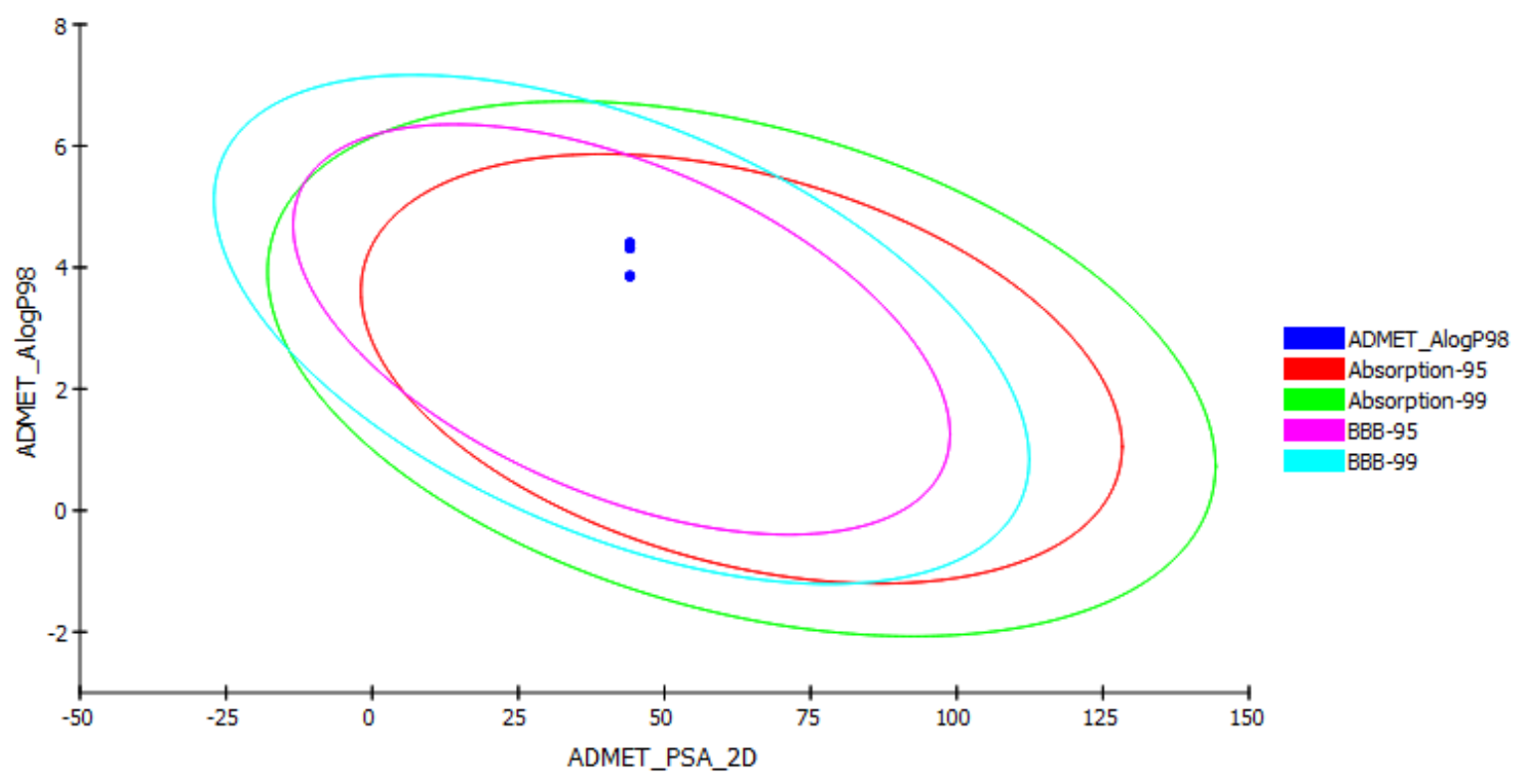

Figure 9. Predicted pharmacokinetic profile of $\mathbf{C H}$ series.

\section{Conclusions}

In summary, two sets of trimethoxylated halogenated chalcones were synthesized, characterized, and evaluated for their MAO and BACE- 1 inhibitory activities. $\mathrm{CH} 4$ and $\mathrm{CH} 5$ were revealed as competitive and reversible inhibitors of MAO-B, with $\mathrm{K}_{\mathrm{i}}$ values of $0.68 \pm 0.17$ and $0.31 \pm 0.014 \mu \mathrm{M}$, respectively. On the other hand, $\mathrm{CH} 4$ and $\mathrm{CH} 5$ showed good BACE-1 inhibition with $\mathrm{IC}_{50}$ values of 13.6 and $19.8 \mu \mathrm{M}$, respectively. Additionally, $\mathrm{CH} 4$ and $\mathrm{CH} 5$ were found to be safe as analyzed by an in-vitro toxicity study. Additionally, the pro-oxidant and antioxidant levels can be retained by $\mathrm{CH} 4$ and $\mathrm{CH}$. These results suggest that $\mathrm{CH} 4$ and $\mathrm{CH} 5$ could be considered as a potential multi-targeted ligand for the treatment of neurological disorders.

Supplementary Materials: Available online at https:/ /www.mdpi.com/article/10.3390/pharmaceutics1 3060850/s1, spectral interpretation; cytotoxicity studies; ROS Assay; MUSSEL Prediction; Toxicity Predicition.

Author Contributions: Conceptualization: B.M. and H.K.; synthesis: V.P.K., A.S.N. and B.M.; biological activity: J.M.O., A.K., M.A.A. and L.R.N.; docking analysis: N.G., F.C. and O.N.; original draft writing: B.M.; review and editing: H.K. and B.M.; supervision: H.K.; funding acquisition: H.K. and A.K. All authors have read and agreed to the published version of the manuscript.

Funding: This study was supported by the National Research Foundation of Korea (NRF) grant provided by the Korean Government (NRF-2019R1A2C1088967 to H. Kim), Republic of Korea, and by a grant from Amrita Vishwa Vidyapeetham University (Seed Grant Number K-PHAR-20-628 to B. Mathew).

Institutional Review Board Statement: Not applicable.

Informed Consent Statement: Not applicable.

Data Availability Statement: All data generated or analyzed during this study have been included in this article. 
Acknowledgments: Authors acknowledge Taif University Researchers Supporting Project number (TURSP-2020/68), Taif University, Taif, Saudi Arabia.

Conflicts of Interest: The authors declare no conflict of interest.

\section{References}

1. Youdim, M.B.; Edmondson, D.; Tipton, K.F. The therapeutic potential of monoamine oxidase inhibitors. Nat. Rev. Neurosci. 2006, 7, 295-309. [CrossRef]

2. Carradori, S.; Secci, D.; Petzer, J.P. MAO inhibitors and their wider applications: A patent review. Expert Opin. Ther. Pat. 2018, 28, 211-226. [CrossRef]

3. Manzoor, S.; Hoda, N. A comprehensive review of monoamine oxidase inhibitors as Anti-Alzheimer's disease agents: A review. Eur. J. Med. Chem. 2020, 206, 112787. [CrossRef] [PubMed]

4. Dezsi, L.; Vecsei, L. Monoamine oxidase B inhibitors in Parkinson's disease. CNS Neurol. Disord. Drug Targets 2017, 16, 425-439. [CrossRef] [PubMed]

5. Riederer, P.; Müller, T. Use of monoamine oxidase inhibitors in chronic neurodegeneration. Expert Opin. Drug Metab. Toxicol. 2017, 13, 233-240. [CrossRef]

6. Tripathi, R.K.P.; Ayyannan, S.R. Monoamine oxidase-B inhibitors as potential neurotherapeutic agents: An overview and update. Med. Res. Rev. 2019, 39, 1603-1706. [CrossRef]

7. Guglielmi, P.; Carradori, S.; Ammazzalorso, A.; Secci, D. Novel approaches to the discovery of selective human monoamine oxidase-B inhibitors: Is there room for improvement? Expert Opin. Drug Discov. 2019, 14, 995-1035. [CrossRef] [PubMed]

8. Hong, R.; Li, X. Discovery of monoamine oxidase inhibitors by medicinal chemistry approaches. Medchemcomm 2018, 10, 10-25. [CrossRef] [PubMed]

9. Youdim, M.B.; Bakhle, Y.S. Monoamine oxidase: Isoforms and inhibitors in Parkinson's disease and depressive illness. Br. J. Pharmacol. 2006, 147, S287-S296. [CrossRef]

10. Ramsay, R.R.; Albreht, A. Kinetics, mechanism, and inhibition of monoamine oxidase. J. Neural Transm. 2018, 125, 1659-1683. [CrossRef]

11. Ghosh, A.K.; Osswald, H.L. BACE1 ( $\beta$-secretase) inhibitors for the treatment of Alzheimer's disease. Chem. Soc. Rev. 2014, 43, 6765-6813. [CrossRef]

12. Kumar, D.; Ganeshpurkar, A.; Kumar, D.; Modi, G.; Gupta, S.K.; Singh, S.K. Secretase inhibitors for the treatment of Alzheimer's disease: Long road ahead. Eur. J. Med. Chem. 2018, 148, 436-452. [CrossRef] [PubMed]

13. Moussa-Pacha, N.M.; Abdin, S.M.; Omar, H.A.; Alniss, H.; Al-Tel, T.H. BACE1 inhibitors: Current status and future directions in treating Alzheimer's disease. Med. Res. Rev. 2020, 40, 339-384. [CrossRef]

14. León, R.; Garcia, A.G.; Marco-Contelles, J. Recent advances in the multitarget-directed ligands approach for the treatment of Alzheimer's disease. Med. Res. Rev. 2013, 33, 139-189. [CrossRef] [PubMed]

15. Schaduangrat, N.; Prachayasittikul, V.; Choomwattana, S.; Wongchitrat, P.; Phopin, K.; Suwanjang, W.; Malik, A.A.; Vincent, B.; Nantasenamat, C. Multidisciplinary approaches for targeting the secretase protein family as a therapeutic route for Alzheimer's disease. Med. Res. Rev. 2019, 39, 1730-1778. [CrossRef] [PubMed]

16. Huang, C.; Zhang, W.; Sheng, C.; Zhang, W.; Xing, C.; Miao, Z. Chalcone: A privileged structure in medicinal chemistry. Chem. Rev. 2017, 117, 7762-7810.

17. Matos, M.J.; Vazquez-Rodriguez, S.; Uriarte, E.; Santana, L. Potential pharmacological uses of chalcones: A patent review. Expert Opin. Ther. Pat. 2015, 25, 351-366. [CrossRef]

18. Singh, P.; Anand, A.; Kumar, V. Recent developments in biological activities of chalcones: A mini review. Eur. J. Med. Chem. 2014, 85, 758-777. [CrossRef]

19. Sharma, R.; Kumar, R.; Kodwani, R.; Kapoor, S.; Khare, A.; Bansal, R.; Khurana, S.; Singh, S.; Thomas, J.; Roy, B.; et al. A review on mechanisms of anti tumor activity of chalcones. Anticancer Agents Med. Chem. 2015, 16, 200-211. [CrossRef]

20. Nowakowska, Z. A review of anti-infective and anti-inflammatory chalcones. Eur. J. Med. Chem. 2007, 42, 125-137. [CrossRef]

21. Rocha, S.; Ribeiro, D.; Fernandes, E.; Freitas, M. A systematic review on anti-diabetic properties of chalcones. Curr. Med. Chem. 2020, 27, 2257-2321. [CrossRef]

22. Mathew, B.; Parambi, D.G.T.; Sivasankarapillai, V.S.; Uddin, M.S.; Suresh, J.; Mathew, G.E.; Joy, M.; Marathakam, A.; Gupta, S.V. Perspective design of chalcones for the management of CNS disorders: A mini-review. CNS Neurol. Disord. Drug Targets 2019, 18, 432-445. [CrossRef]

23. Wilcken, R.; Zimmermann, M.O.; Lange, A.; Joerger, A.C.; Boeckler, F.M. Principles and applications of halogen bonding in medicinal chemistry and chemical biology. J. Med. Chem. 2013, 56, 1363-1388. [CrossRef] [PubMed]

24. Lu, Y.; Wang, Y.; Xu, Z.; Yan, X.; Luo, X.; Jiang, H.; Zhu, W. C-X - . H contacts in biomolecular systems: How they contribute to protein-ligand binding affinity. J. Phys. Chem. B. 2009, 113, 12615-12621. [CrossRef] [PubMed]

25. Mathew, B.; Carradori, S.; Guglielmi, P.; Uddin, M.S.; Kim, H. New aspects of monoamine oxidase b inhibitors: The key role of halogens to open the golden door. Curr. Med. Chem. 2021, 28, 266-283. [CrossRef] [PubMed]

26. Mathew, B.; Mathew, G.E.; Uçar, G.; Baysal, I.; Suresh, J.; Vilapurathu, J.K.; Prakasan, A.; Suresh, J.K.; Thomas, A. Development of fluorinated methoxylated chalcones as selective monoamine oxidase-B inhibitors: Synthesis, biochemistry and molecular docking studies. Bioorg. Chem. 2015, 62, 22-29. [CrossRef] 
27. Morales-Camilo, N.; Salas, C.O.; Sanhueza, C.; Espinosa-Bustos, C.; Sepúlveda-Boza, S.; Reyes-Parada, M.; Gonzalez-Nilo, F.; Caroli-Rezende, M.; Fierro, A. Synthesis, biological evaluation, and molecular simulation of chalcones and aurones as selective MAO-B inhibitors. Chem. Biol. Drug Des. 2015, 85, 685-695. [CrossRef]

28. Choi, J.W.; Jang, B.K.; Cho, N.C.; Park, J.H.; Yeon, S.K.; Ju, E.J.; Lee, Y.S.; Han, G.; Pae, A.N.; Kim, D.J.; et al. Synthesis of a series of unsaturated ketone derivatives as selective and reversible monoamine oxidase inhibitors. Bioorg. Med. Chem. 2015, 23, 6486-6496. [CrossRef]

29. Hammuda, A.; Shalaby, R.; Rovida, S.; Edmondson, D.E.; Binda, C.; Khalil, A. Design and synthesis of novel chalcones as potent selective monoamine oxidase-B inhibitors. Eur. J. Med. Chem. 2016, 114, 162-169. [CrossRef]

30. Mathew, B.; Uçar, G.; Mathew, G.E.; Mathew, S.; Purapurath, K.P.; Moolayil, F.; Mohan, S.; Gupta, S.V. Monoamine oxidase inhibitory activity: Methyl- versus Chloro chalcone derivatives. Chem. Med. Chem. 2016, 11, 2649-2655. [CrossRef]

31. Mathew, B.; Mathew, G.E.; Ucar, G.; Joy, M.; Nafna, E.K.; Lohidakshan, K.K.; Suresh, J. Monoamine oxidase inhibitory activity of methoxy-substituted chalcones. Int. J. Biol. Macromol. 2017, 104, 1321-1329. [CrossRef] [PubMed]

32. Chimenti, F.; Fioravanti, R.; Bolasco, A.; Chimenti, P.; Secci, D.; Rossi, F.; Yáñez, M.; Orallo, F.; Ortuso, F.; Alcaro, S. Chalcones: A valid scaffold for monoamine oxidases inhibitors. J. Med. Chem. 2009, 52, 2818-2824. [CrossRef]

33. Minders, C.; Petzer, J.P.; Petzer, A.; Lourens, A.C. Monoamine oxidase inhibitory activities of heterocyclic chalcones. Bioorg. Med. Chem. Lett. 2015, 25, 5270-5276. [CrossRef]

34. Sasidharan, R.; Manju, S.L.; Uçar, G.; Baysal, I.; Mathew, B. Identification of indole-based chalcones: Discovery of a potent, selective, and reversible class of MAO-B inhibitors. Arch. Pharm. 2016, 349, 627-637. [CrossRef]

35. Mathew, B.; Haridas, A.; Uçar, G.; Baysal, I.; Joy, M.; Mathew, G.E.; Lakshmanan, B.; Jayaprakash, V. Synthesis, biochemistry, and computational studies of brominated thienyl chalcones: A new class of reversible MAO-B Inhibitors. Chem. Med. Chem. 2016, 11, 1161-1171. [CrossRef] [PubMed]

36. Xiao, G.; Li, Y.; Qiang, X.; Xu, R.; Zheng, Y.; Cao, Z.; Luo, L.; Yang, X.; Sang, Z.; Su, F.; et al. Design, synthesis and biological evaluation of $4^{\prime}$-aminochalcone-rivastigmine hybrids as multifunctional agents for the treatment of Alzheimer's disease. Bioorg. Med. Chem. 2017, 25, 1030-1041. [CrossRef]

37. Cao, Z.; Yang, J.; Xu, R.; Song, Q.; Zhang, X.; Liu, H.; Qiang, X.; Li, Y.; Tan, Z.; Deng, Y. Design, synthesis and evaluation of $4^{\prime}$-OH-flurbiprofen-chalcone hybrids as potential multifunctional agents for Alzheimer's disease treatment. Bioorg. Med. Chem. 2018, 26, 1102-1115. [CrossRef]

38. Sasidharan, R.; Baek, S.C.; Sreedharannair Leelabaiamma, M.; Kim, H.; Mathew, B. Imidazole bearing chalcones as a new class of monoamine oxidase inhibitors. Biomed. Pharmacother. 2018, 106, 8-13. [CrossRef] [PubMed]

39. Suresh, J.; Baek, S.C.; Ramakrishnan, S.P.; Kim, H.; Mathew, B. Discovery of potent and reversible MAO-B inhibitors as furanochalcones. Int. J. Biol. Macromol. 2018, 108, 660-664. [CrossRef]

40. Reeta; Baek, S.C.; Lee, J.P.; Rangarajan, T.M.; Ayushee; Singh, R.P.; Singh, M.; Mangiatordi, G.F.; Nicolotti, O.; Kim, H.; et al. Ethyl acetohydroxamate incorporated chalcones: Unveiling a novel class of chalcones for multitarget monoamine oxidase-B inhibitors against Alzheimer's disease. CNS Neurol. Disord. Drug Targets 2019, 18, 643-654. [CrossRef]

41. Mathew, B.; Baek, S.C.; Thomas Parambi, D.G.; Lee, J.P.; Mathew, G.E.; Jayanthi, S.; Vinod, D.; Rapheal, C.; Devikrishna, V.; Kondarath, S.S.; et al. Potent and highly selective dual-targeting monoamine oxidase-B inhibitors: Fluorinated chalcones of morpholine versus imidazole. Arch. Pharm. 2019, 352, e1800309. [CrossRef] [PubMed]

42. Parambi, D.G.T.; Oh, J.M.; Baek, S.C.; Lee, J.P.; Tondo, A.R.; Nicolotti, O.; Kim, H.; Mathew, B. Design, synthesis and biological evaluation of oxygenated chalcones as potent and selective MAO-B inhibitors. Bioorg. Chem. 2019, 93, 103335. [CrossRef]

43. Sang, Z.; Wang, K.; Zhang, P.; Shi, J.; Liu, W.; Tan, Z. Design, synthesis, in-silico and biological evaluation of novel chalcone derivatives as multi-function agents for the treatment of Alzheimer's disease. Eur. J. Med. Chem. 2019, 180, 238-252. [CrossRef]

44. Zhang, X.; Song, Q.; Cao, Z.; Li, Y.; Tian, C.; Yang, Z.; Zhang, H.; Deng, Y. Design, synthesis and evaluation of chalcone Mannich base derivatives as multifunctional agents for the potential treatment of Alzheimer's disease. Bioorg. Chem. 2019, 87, 395-408. [CrossRef]

45. Shalaby, R.; Petzer, J.P.; Petzer, A.; Ashraf, U.M.; Atari, E.; Alasmari, F.; Kumarasamy, S.; Sari, Y.; Khalil, A. SAR and molecular mechanism studies of monoamine oxidase inhibition by selected chalcone analogs. J. Enzyme Inhib. Med. Chem. 2019, 34, 863-876. [CrossRef]

46. Bai, P.; Wang, K.; Zhang, P.; Shi, J.; Cheng, X.; Zhang, Q.; Zheng, C.; Cheng, Y.; Yang, J.; Lu, X.; et al. Development of chalcone-Oalkylamine derivatives as multifunctional agents against Alzheimer's disease. Eur. J. Med. Chem. 2019, 183, 111737. [CrossRef] [PubMed]

47. Oh, J.M.; Rangarajan, T.M.; Chaudhary, R.; Singh, R.P.; Singh, M.; Singh, R.P.; Tondo, A.R.; Gambacorta, N.; Nicolotti, O.; Mathew, B.; et al. Novel class of chalcone oxime ethers as potent monoamine oxidase-B and acetylcholinesterase inhibitors. Molecules 2020, 25, 2356. [CrossRef]

48. Jeong, G.S.; Kaipakasseri, S.; Lee, S.R.; Marraiki, N.; Batiha, G.E.; Dev, S.; Palakkathondi, A.; Kavully, F.S.; Gambacorta, N.; Nicolotti, O.; et al. Selected 1,3-benzodioxine-containing chalcones as multipotent oxidase and acetylcholinesterase inhibitors. ChemMedChem 2020, 15, 2257-2263. [CrossRef] [PubMed]

49. Kong, Z.; Sun, D.; Jiang, Y.; Hu, Y. Design, synthesis, and evaluation of 1, 4-benzodioxan-substituted chalcones as selective and reversible inhibitors of human monoamine oxidase B. J. Enzyme Inhib. Med. Chem. 2020, 35, 1513-1523. [CrossRef] [PubMed] 
50. Sasidharan, R.; Eom, B.H.; Heo, J.H.; Park, J.E.; Abdelgawad, M.A.; Musa, A.; Gambacorta, N.; Nicolotti, O.; Manju, S.L.; Mathew, B.; et al. Morpholine-based chalcones as dual-acting monoamine oxidase-B and acetylcholinesterase inhibitors: Synthesis and biochemical investigations. J. Enzyme Inhib. Med. Chem. 2021, 36, 188-197. [CrossRef] [PubMed]

51. Zhang, X.; Rakesh, K.P.; Bukhari, S.N.A.; Balakrishna, M.; Manukumar, H.M.; Qin, H.L. Multi-targetable chalcone analogs to treat deadly Alzheimer's disease: Current view and upcoming advice. Bioorg. Chem. 2018, 80, 86-93. [CrossRef] [PubMed]

52. Guglielmi, P.; Mathew, B.; Secci, D.; Carradori, S. Chalcones: Unearthing their therapeutic possibility as monoamine oxidase B inhibitors. Eur. J. Med. Chem. 2020, 205, 112650. [CrossRef]

53. Mathew, B. Privileged pharmacophore of FDA approved drugs in combination with chalcone framework: A new hope for alzheimer's treatment. Comb. Chem. High Throughput Screen. 2020, 23, 842-846. [CrossRef] [PubMed]

54. Burmaoglu, S.; Kazancioglu, E.A.; Kaya, R.; Kazancioglu, M.; Karaman, M.; Algul, O.; Gulcin, I. Synthesis of novel organohalogen chalcone derivatives and screening of their molecular docking study and some enzymes inhibition effects. J. Mol. Struct. 2020, 1208, 127868. [CrossRef]

55. Mathew, B.; Baek, S.C.; Grace Thomas Parambi, D.; Pil Lee, J.; Joy, M.; Annie Rilda, P.R.; Randev, R.V.; Nithyamol, P.; Vijayan, V.; Inasu, S.T.; et al. Selected aryl thiosemicarbazones as a new class of multi-targeted monoamine oxidase inhibitors. MedChemComm 2018, 9, 1871-1881. [CrossRef]

56. Mathew, B.; Oh, J.M.; Baty, R.S.; Batiha, G.E.; Parambi, D.G.T.; Gambacorta, N.; Nicolotti, O.; Kim, H. Piperazine-substituted chalcones: A new class of MAO-B, AChE, and BACE-1 inhibitors for the treatment of neurological disorders. Environ. Sci. Pollut. Res. 2021. [CrossRef] [PubMed]

57. Nair, A.S.; Oh, J.-M.; Koyiparambath, V.P.; Kumar, S.; Sudevan, S.T.; Soremekun, O.; Soliman, M.E.; Khames, A.; Abdelgawad, M.A.; Pappachen, L.K.; et al. Development of halogenated pyrazolines as selective monoamine oxidase-B Inhibitors: Deciphering via molecular dynamics approach. Molecules 2021, 26, 3264. [CrossRef] [PubMed]

58. Oh, J.M.; Jang, H.J.; Kim, W.J.; Kang, M.G.; Baek, S.C.; Lee, J.P.; Park, D.; Oh, S.R.; Kim, H. Calycosin and 9-O-methylretusin isolated from Maackia amurensis as potent and selective reversible inhibitors of human monoamine oxidase-B. Int. J. Biol. Macromol. 2020, 151, 441-448. [CrossRef] [PubMed]

59. Fotakis, G.; Timbrell, J.A. In vitro cytotoxicity assays: Comparison of LDH, neutral red, MTT and protein assay in hepatoma cell lines following exposure to cadmium chloride. Toxicol. Lett. 2006, 160, 171-177. [CrossRef] [PubMed]

60. Jambunathan, N. Determination and detection of reactive oxygen species (ROS), lipid peroxidation, and electrolyte leakage in plants. Methods Mol. Biol. 2010, 639, 292-298.

61. Di, L.; Kerns, E.H.; Fan, K.; McConnell, O.J.; Carter, G.T. High throughput artificial membrane permeability assay for blood-brain barrier. Eur. J. Med. Chem. 2003, 38, 223-232. [CrossRef]

62. Son, S.Y.; Ma, J.; Kondou, Y.; Yoshimura, M.; Yamashita, E.; Tsukihara, T. Structure of human monoamine oxidase A at 2.2-A resolution: The control of opening the entry for substrates/inhibitors. Proc. Natl. Acad. Sci. USA 2008, 105, 5739-5744. [CrossRef] [PubMed]

63. Binda, C.; Wang, J.; Pisani, L.; Caccia, C.; Carotti, A.; Salvati, P.; Edmondson, D.E.; Mattevi, A. Structures of human monoamine oxidase B complexes with selective noncovalent inhibitors: Safinamide and coumarin analogs. J. Med. Chem. 2007, 50, 5848-5852. [CrossRef]

64. Xu, Y.; Li, M.; Greenblatt, H.; Chen, W.; Paz, A.; Dym, O.; Peleg, Y.; Chen, T.; Shen, X.; He, J.; et al. Flexibility of the flap in the active site of BACE1 as revealed by crystal structures and molecular dynamics simulations. Acta Cryst. D 2012, 68, 13-25. [CrossRef]

65. Schrödinger Release 2020-4: Protein Preparation Wizard; Epik, Schrödinger, LLC: New York, NY, USA, 2016.

66. Madhavi Sastry, G.; Adzhigirey, M.; Day, T.; Annabhimoju, R.; Sherman, W. Protein and Ligand Preparation: Parameters, protocols, and influence on virtual screening enrichments. J. Comput. Aided. Mol. Des. 2013, 27, 221-234. [CrossRef]

67. Schrödinger Release 2020-4: LigPrep; Schrödinger, LLC: New York, NY, USA, 2020.

68. Friesner, R.A.; Banks, J.L.; Murphy, R.B.; Halgren, T.A.; Klicic, J.J.; Mainz, D.T.; Repasky, M.P.; Knoll, E.H.; Shelley, M.; Perry, J.K.; et al. Glide: A new approach for rapid, accurate docking and scoring. 1. Method and assessment of docking accuracy. J. Med. Chem. 2004, 47, 1739-1749. [CrossRef]

69. Available online: http:/ / www.caesar-project.eu (accessed on 21 May 2021).

70. Available online: http:// predherg.labmol.com.br/ (accessed on 21 May 2021).

71. Mathew, B.; Adeniyi, A.A.; Joy, M.; Mathew, G.E.; Ashona Singh-Pillay, A.S.; Sudarsanakumar, C.; Soliman, M.E.S.; Suresh, J. Anti-oxidant behavior of functionalized chalcone-a combined quantum chemical and crystallographic structural investigation. $J$. Mol. Struct. 2017, 1146, 301-308. [CrossRef]

72. Kumar, V.; Sharma, N.; Maitra, S.S. In vitro and in vivo toxicity assessment of nanoparticles. Int. Nano Lett. 2007, 7, 243-256. [CrossRef]

73. Zuo, L.; Zhou, T.; Pannell, B.K.; Ziegler, A.C.; Best, T.M. Biological and physiological role of reactive oxygen species-The good, the bad and the ugly. Acta Physiol. (Oxf.) 2015, 214, 329-348. [CrossRef]

74. Park, C.; Cha, H.J.; Hong, S.H.; Kim, G.Y.; Kim, S.; Kim, H.S.; Kim, B.W.; Jeon, Y.J.; Choi, Y.H. Protective effect of phloroglucinol on oxidative stress-induced DNA damage and apoptosis through activation of the Nrf2/HO-1 signaling pathway in HaCaT human keratinocytes. Mar. Drugs 2019, 17, 225. [CrossRef] 
75. Alberga, D.; Trisciuzzi, D.; Montaruli, M.; Leonetti, F.; Mangiatordi, G.F.; Nicolotti, O. A new approach for drug target and bioactivity prediction: The multifingerprint similarity search algorithm (MuSSeL). J. Chem. Inf. Model. 2019, 59, 586-596. [CrossRef]

76. Montaruli, M.; Alberga, D.; Ciriaco, F.; Trisciuzzi, D.; Tondo, A.R.; Mangiatordi, G.F.; Nicolotti, O. Accelerating drug discovery by early protein drug target prediction based on a multi-fingerprint similarity search. Molecules 2019, 24, 2233. [CrossRef] [PubMed]

77. Nicolotti, O.; Benfenati, E.; Carotti, A.; Gadaleta, D.; Gissi, A.; Mangiatordi, G.F.; Novellino, E. REACH and in silico methods: An attractive opportunity for medicinal chemists. Drug Discov. Today 2014, 19, 1757-1768. [CrossRef] [PubMed]

78. Cavalluzzi, M.M.; Imbrici, P.; Gualdani, R.; Stefanachi, A.; Mangiatordi, G.F.; Lentini, G.; Nicolotti, O. Human ether-à-gogo-related potassium channel: Exploring SAR to improve drug design. Drug Discov. Today 2020, 25, 344-366. [CrossRef] [PubMed]

79. Mangiatordi, G.F.; Alberga, D.; Altomare, C.D.; Carotti, A.; Catto, M.; Cellamare, S.; Gadaleta, D.; Lattanzi, G.; Leonetti, F.; Pisani, L.; et al. Mind the gap! A journey towards computational toxicology. Mol. Inform. 2016, 35, 294-308. [CrossRef] [PubMed]

80. Ferrari, T.; Gini, G. An open source multistep model to predict mutagenicity from statistical analysis and relevant structural alerts. Chem Cent. J. 2010, 4, S2. [CrossRef]

81. Braga, R.C.; Alves, V.M.; Silva, M.F.; Muratov, E.; Fourches, D.; Lião, L.M.; Tropsha, A.; Andrade, C.H. Pred-hERG: A novel web-accessible computational tool for predicting cardiac toxicity. Mol. Inform. 2015, 34, 698-701. [CrossRef] 